\title{
Chemical Space Exploration of Oxetanes
}

\author{
Fernando Rodrigues de Sá Alves ${ }^{1}$, Rafael M. Couñago ${ }^{2}$ (I) and Stefan Laufer ${ }^{1,3, *(1)}$ \\ 1 Department of Pharmaceutical and Medicinal Chemistry, Institute of Pharmaceutical Sciences, \\ Faculty of Science, Eberhard Karls University of Tübingen, 72074 Tübingen, Germany; \\ fernandorodriguessalves@gmail.com \\ 2 Centro de Química Medicinal (CQMED), Centro de Biologia Molecular e Engenharia Genética (CBMEG), \\ Structural Genomics Consortium, Departamento de Genética e Evolução, Instituto de Biologia Universidade \\ Estadual de Campinas (UNICAMP), Campinas 13083-875, SP, Brazil; rafaelcounago@gmail.com \\ 3 Tübingen Center for Academic Drug Discovery, 72076 Tübingen, Germany \\ * Correspondence: stefan.laufer@uni-tuebingen.de
}

Received: 7 October 2020; Accepted: 28 October 2020; Published: 2 November 2020

\begin{abstract}
This paper focuses on new derivatives bearing an oxetane group to extend accessible chemical space for further identification of kinase inhibitors. The ability to modulate kinase activity represents an important therapeutic strategy for the treatment of human illnesses. Known as a nonclassical isoster of the carbonyl group, due to its high polarity and great ability to function as an acceptor of hydrogen bond, oxetane seems to be an attractive and underexplored structural motif in medicinal chemistry.
\end{abstract}

Keywords: oxetane; chemical space; nonclassical isosterism; Buchwald-Hartwig reaction; kinases

\section{Introduction}

Oxetane is a four-membered ring having an oxygen atom with an intrinsic ring strain of $106 \mathrm{~kJ} \cdot \mathrm{mol}^{-1}$, which adopts a planar structure with a puckering angle of only $8.7^{\circ}$ at $140 \mathrm{~K}\left(10.7^{\circ}\right.$ at $\left.90 \mathrm{~K}\right)$. The addition of substituents into the oxetane ring can increment unfavorable eclipsing interactions, resulting in a more puckered conformation [1].

The strained $\mathrm{C}-\mathrm{O}-\mathrm{C}$ bond angle exposes the oxygen lone pair of electrons, allowing the oxetane to act as a good hydrogen-bond acceptor as well as donating electron density as a Lewis base. It was also observed experimentally that oxetanes form more effective H-bonds than other cyclic ethers [2]. Similarly, oxetanes compete as $\mathrm{H}$-bond acceptors with the majority of carbonyl functional groups like aliphatic ketones, aldehydes, and esters [3]. These structural features are important for many of the beneficial properties of substituted oxetanes.

Some examples of compounds bearing the oxetane are oxetanocin $A$, thromboxane $A_{2}$, mitrephorone A, oxetine and laureatin, as well as the marketed chemotherapy drugs Taxol and Taxotere and a new kinase inhibitor GS-9876 (Figure 1).

In medicinal chemistry, an oxetane group is employed not only to change the conformational preference of the main scaffold but also to influence physicochemical and biochemical properties such as lipophilicity, aqueous solubility, and metabolic stability [4]. Carreira and co-workers from ETH Zurich have been using oxetanes as surrogates of a carbonyl group in order to generate building blocks providing new opportunities of molecular diversity [5-7]. The group of Professor Bull from Imperial College London has also been working extensively on the synthesis and new methodologies for obtaining compounds bearing an oxetane [8-10]. Recently, Blomgren and co-workers have reported the discovery of a second-generation spleen tyrosine kinase inhibitor, GS-9876 (lanraplenib), which has human pharmacokinetic properties suitable for once-daily administration and it is used against autoimmune diseases [11]. Known as a nonclassical isoster of the carbonyl group [12], due to its high 
polarity and great ability to function as an acceptor of hydrogen bond, the oxetane still remains an underexplored structural motif in drug discovery, especially in the kinase field, in which the oxetane could bind the "hinge" region (Figure 2). Nevertheless, the conformational variations or the directional hydrogen bonding differences between $\mathrm{sp}_{2}$ - and $\mathrm{sp}_{3}$-hybridized oxygen atoms could be a benefit or a drawback for that type of interaction.<smiles>Nc1ncnc2c1ncn2[C@@H]1O[C@H](CO)[C@@H]1CO</smiles>

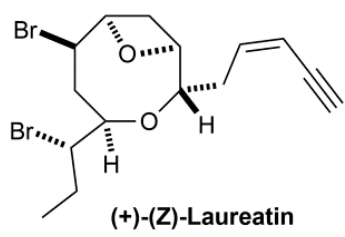<smiles>NC1COC1C(=O)O</smiles><smiles>Nc1cncc(-c2cn3ccnc3c(Nc3ccc(N4CCN(C5COC5)CC4)cc3)n2)n1</smiles>

Lanraplenib (GS-9876)

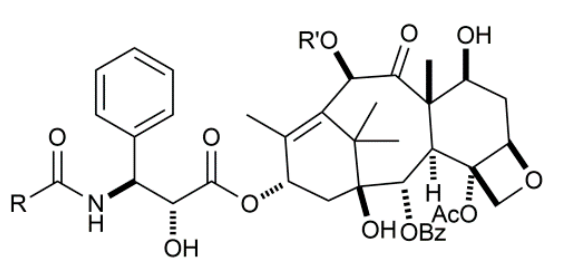

$\mathbf{R}=\mathbf{P h}, \mathbf{R}^{\prime}=\mathbf{A c}$, Paclitaxel $($ Taxol) $\mathbf{R}=\mathbf{O} \mathbf{t B u}^{\mathrm{B}}, \mathbf{R}^{\prime}=\mathrm{H}$, Docetaxel (Taxotere)<smiles></smiles>

Thromboxane $\mathbf{A}_{2}$

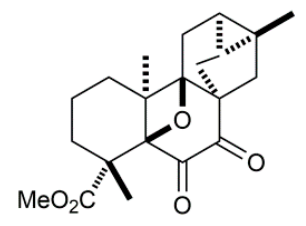

Mitrephorone A

Figure 1. Natural products and marketed drugs containing an oxetane group.

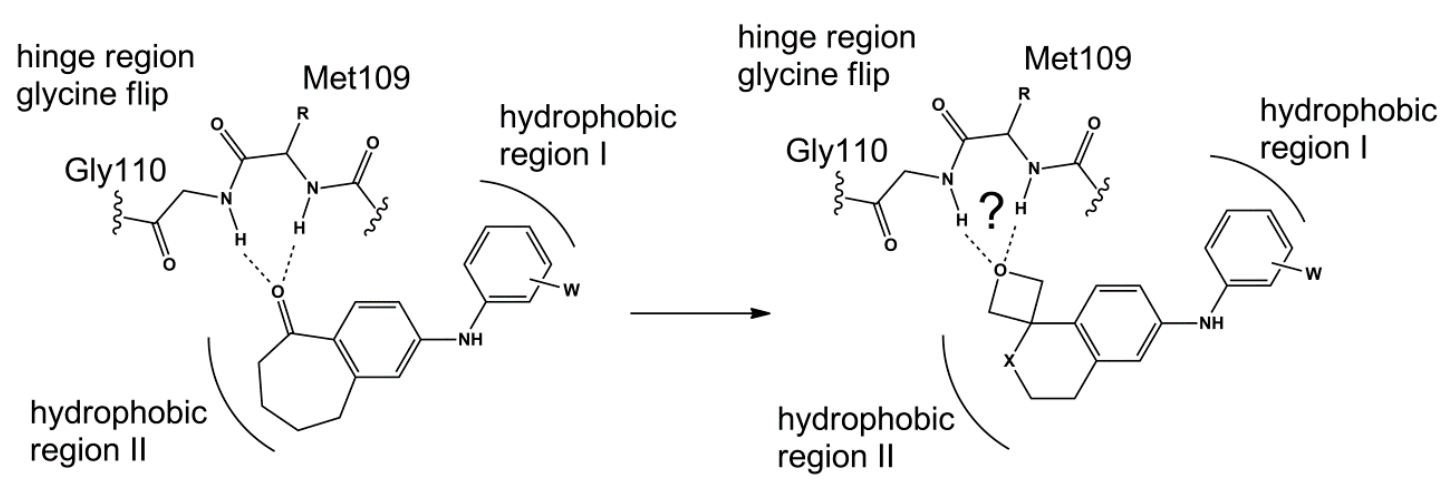

Figure 2. Schematic of the interactions of benzosuberone and oxetane analogs in the hinge region.

\section{Results and Discussion}

Our main goal was to synthesize new oxetane derivatives to further extend the therapeutical kinase space. We proposed the nonclassical isosteric replacement of the carbonyl group of some kinase inhibitors bearing dibenzosuberone and benzophenone scaffolds by an oxetane moiety (Figure 3). This substitution could lead to an interaction of the oxetane group with the "hinge" region. All protein kinases contain a sequence of amino acids comprising the "hinge" between the two lobes of the catalytic domain. The backbone atoms of the hinge region contain the critical hydrogen bond donor and acceptor atoms anchoring ATP-binding and allowing phosphorylation of the substrate [13]. 


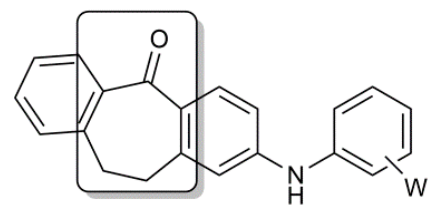<smiles>N#Cc1ccccc1Nc1ccc2c(c1)CCCC21COC1</smiles><smiles>C=CC=CCC1(c2ccc(Nc3ccccc3)cc2CC)COC1</smiles>

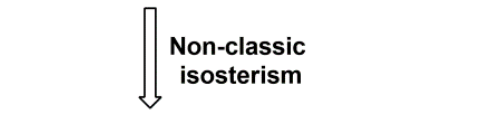
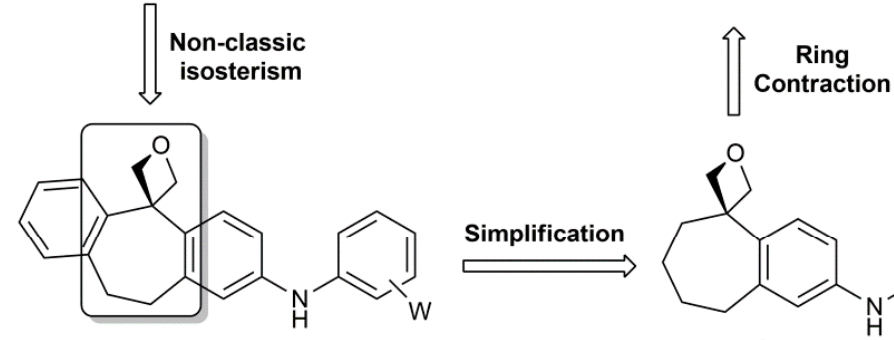

$\int \begin{gathered}\text { Ring } \\ \text { Opening }\end{gathered}$

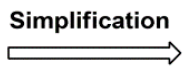<smiles>N#CCNc1ccc2c(c1)CCCCC21COC1</smiles>

2

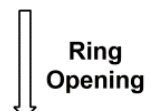<smiles>CC1(c2ccc(Nc3ccccc3)cc2)COC1</smiles><smiles>c1ccc(Nc2ccc(C3(c4ccccc4)COC3)cc2)cc1</smiles>

Figure 3. Design of new oxetane derivatives.

3,3-disubstituted oxetanes can be readily synthesized from 1,3-diols by conversion of the latter into a halohydrin (or another good leaving group) and then by addition of a strong base to close the ring through an intramolecular Williamson etherification reaction [14,15]. However, in the case of 1,3-diols bearing two aryl groups, an 1,4-elimination process namely Grob fragmentation occurs instead of a cyclization, leading to an alkene [16-18]. Thus, a different approach through a catalytic functionalization of tertiary alcohols was used in order to obtain 3,3-diphenyloxetane derivatives (Figure 4).

\section{Strategy 1}

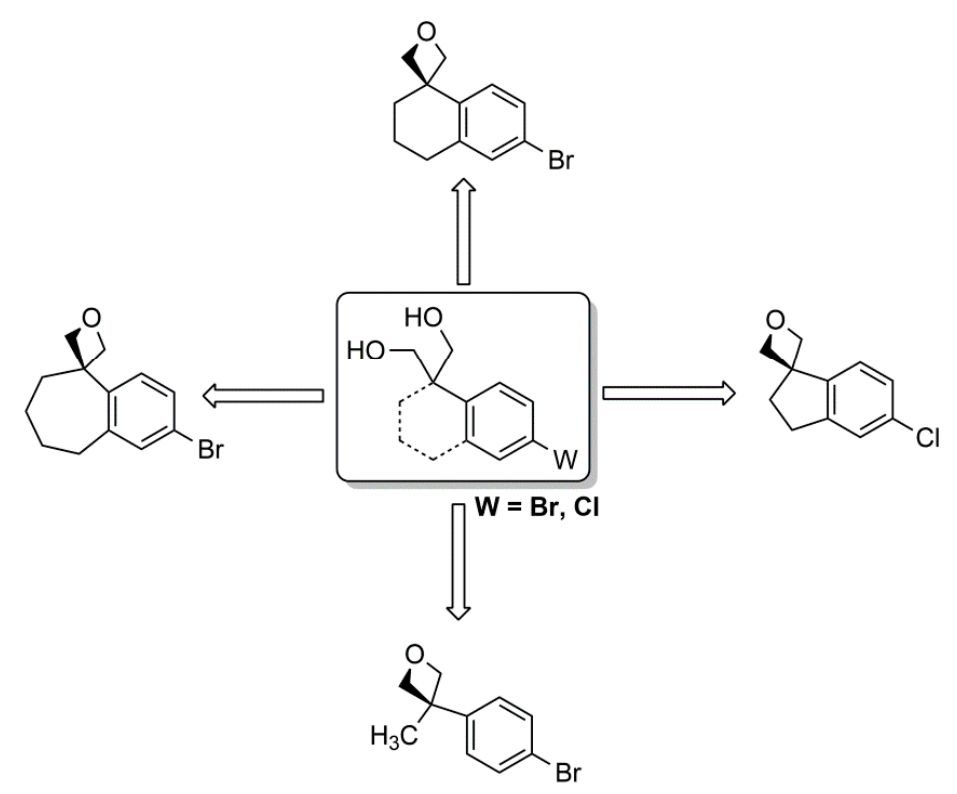

Strategy 2<smiles>O=C(Oc1ccccc1)c1ccc(C(=O)C(=O)c2ccc(O)cc2)cc1</smiles><smiles>C=CCCC(=O)c1ccc(OC(=O)c2ccccc2)cc1</smiles>

Figure 4. Strategies used to synthesize the oxetane scaffolds. 
The ketones 1a-c reacted with dimethylsulfonium methylide in a Corey-Chaykovsky epoxidation reaction [19], leading to the epoxide derivatives $\mathbf{2 a - c}$. In the next step, the aldehydes 3a-c were obtained through a Lewis acid catalyzed epoxide rearrangement by a 1,2-hydride shift, namely Meinwald rearrangement [20]. Then a crossed Cannizzaro reaction was performed [21], reacting the aldehydes with formaldehyde in concentrated basic conditions, obtaining the 1,3-diol derivatives $4 \mathbf{a}-\mathbf{c}$. For the synthesis of the oxetanes applying strategy 1 , we used the concept of hydroxyl replacement via oxyphosphonium salts, in which phosphonium salts can also be formed by reaction of different trivalent phosphorus compounds with oxidizing electrophiles, like the tris(dimethylamino)phosphine-carbon tetrachloride component system. The produced phosphonium intermediates can be trapped with an alcohol to form alkoxyphosphonium salts, which can then undergo nucleophilic displacement [22]. Based on the works of Castro and Selve [23], the dialkyloxetanes 5a-c were obtained in good yields (Scheme 1).

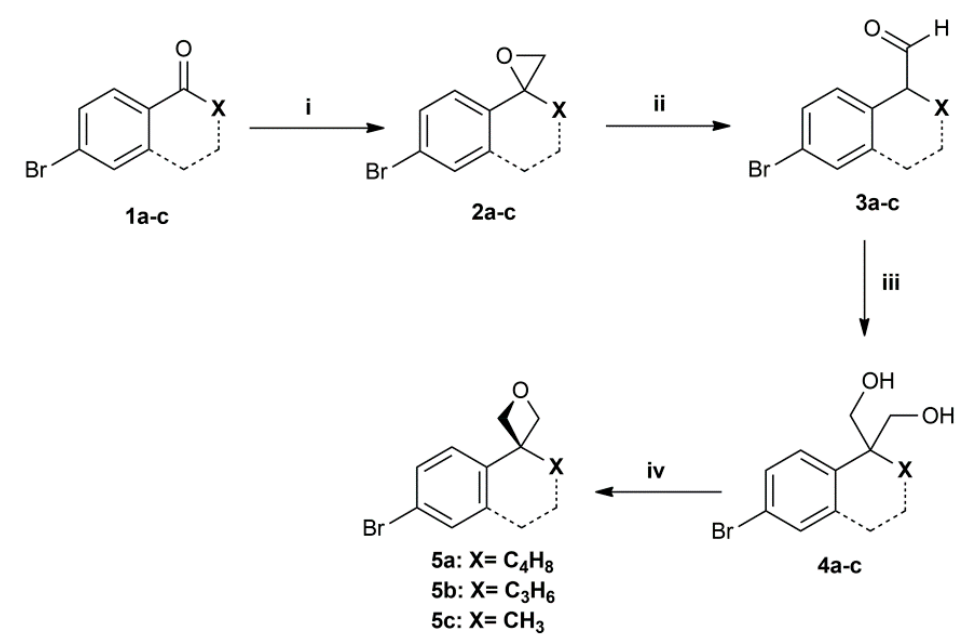

Scheme 1. Reagents and Conditions: (i) $\left(\mathrm{CH}_{3}\right)_{3} \mathrm{SI}, \mathrm{NaH}, \mathrm{DMSO}$, r.t. (ii) $\mathrm{ZnI}_{2}$, benzene, reflux. (iii) $\mathrm{CH}_{2} \mathrm{O}$, $\mathrm{KOH}$, ethylene glycol, reflux. (iv) 1 . TDAP, $\mathrm{CCl}_{4}, \mathrm{THF},-40^{\circ} \mathrm{C} ; 2$. $\mathrm{NaOMe}, \mathrm{MeOH}$, reflux.

In the case of (5-chloro-2,3-dihydro-1H-indene-1,1-diyl)dimethanol, as the Corey-Chaykovsky epoxidation reaction did not work, the 5-chloro-indanone 6 was converted in compound 7 through a Wittig reaction [24]. Then a Brown hydroboration reaction was carried out followed by oxidation of the borate, in which the alkene was converted into the primary alcohol 8, using hydrogen peroxide in basic conditions $[25,26]$. The alcohol 8 was then oxidized to the aldehyde $\mathbf{9}$ using Dess-Martin periodinane [27] and subsequently converted into the diol $\mathbf{1 0}$ and oxetane $\mathbf{1 1}$ employing the same reactions mentioned before (Scheme 2).
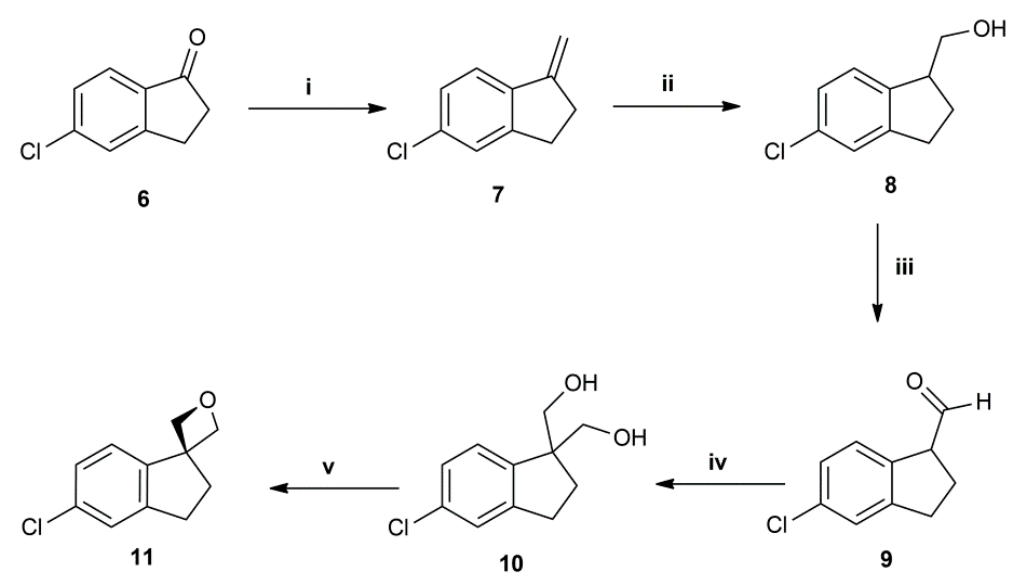

Scheme 2. Reagents and Conditions: (i) 1 . $\mathrm{Ph}_{3} \mathrm{PMeI}, t$-BuOK, THF, $0{ }^{\circ} \mathrm{C}$; 2 . 5-chloro-indanone, $0{ }^{\circ} \mathrm{C}$ to r.t. (ii) 1. $\mathrm{BH}_{3}, \mathrm{THF}, 0^{\circ} \mathrm{C} ; 2$. $\mathrm{NaOH}, \mathrm{H}_{2} \mathrm{O}_{2}, 0{ }^{\circ} \mathrm{C}$-r.t. (iii) Dess-Martin periodinane, $\mathrm{CH}_{2} \mathrm{Cl}_{2}$, r.t. (iv) $\mathrm{CH}_{2} \mathrm{O}, \mathrm{KOH}$, ethylene glycol, reflux. (v) 1 . TDAP, $\mathrm{CCl}_{4}, \mathrm{THF},-40{ }^{\circ} \mathrm{C} ; 2$. $\mathrm{NaOMe}, \mathrm{MeOH}$, reflux. 
The 3,3-diaryloxetane scaffold 14 was synthesized based on the works of Croft and co-workers [28] through the catalytic functionalization of a tertiary alcohol to construct a fully substituted carbon center, using $\mathrm{Li}$ as a catalyst in a Friedel-Crafts alkylation reaction [29]. A halogen-metal exchange reaction of $\mathrm{BuLi}$ and compound 12 , followed by a nucleophilic addition of the organolithium to the carbonyl group of the oxetan-3-one, gave rise to compound 13. The ${ }^{1} \mathrm{H}$ NMR spectrum shows two doublets related to the methylene groups of oxetane, at 4.88 and $4.91 \mathrm{ppm}$. Additionally, the $\mathrm{OH}$ group could be detected as a broad singlet at $2.92 \mathrm{ppm}$. Afterwards, the tertiary alcohol 13 was reacted with phenol, leading to the diaryloxetane $\mathbf{1 4}$ in a 60\% yield. Compound 14 was then converted into the triflate derivative 15 in a $62 \%$ yield [30] (Scheme 3 ).

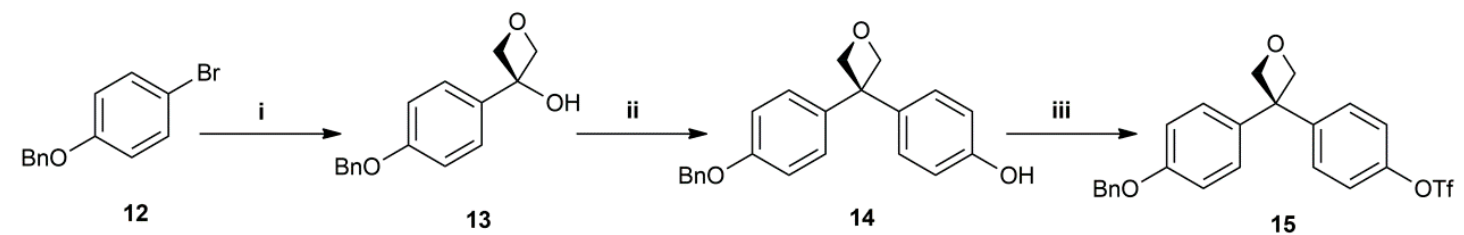

Scheme 3. Reagents and Conditions: (i) $n$-BuLi, oxetan-3-one, THF, $-78{ }^{\circ} \mathrm{C}$. (ii) $\mathrm{Li}\left(\mathrm{NTf}_{2}\right), \mathrm{Bu}_{4} \mathrm{NPF}_{6}$, $\mathrm{CHCl}_{3}, 40^{\circ} \mathrm{C}$. (iii) triflic anhydride, pyridine, $\mathrm{CH}_{2} \mathrm{Cl}_{2}$, r.t.

For the last step, the optimal experimental conditions were established for the Buchwald-Hartwig reaction of the halide scaffolds with arylamines, using a catalyst system composed of $\mathrm{Pd}(\mathrm{OAc})_{2}$, XPhos and $\mathrm{Cs}_{2} \mathrm{CO}_{3}$, in a methodology adapted from our research group for dibenzosuberone derivatives [31]. For the coupling of the aryl triflate with arylamines, a modified method from Buchwald's group was employed [32,33], through a catalyst system composed of $\mathrm{Pd}(\mathrm{OAc})_{2}$, BINAP and $\mathrm{Cs}_{2} \mathrm{CO}_{3}$. No formation of phenol was detected. The deprotection of the benzyloxyl group was carried out with $\mathrm{Pd} / \mathrm{C}$ under $\mathrm{H}_{2}$ atmosphere at r.t. in a mixture of ethanol/acetonitrile, leading to the final compounds in quantitative yields. The oxetane derivatives were reacted with different arylamines. The 2,4-difluoroaniline was initially selected, based on previous works of our laboratory, where it had demonstrated good potency for some kinase inhibitors [34]. Then other modifications were carried out in the arylamine subunit, selecting both electron-withdrawing and donating groups. Additionally, aniline was chosen as a non-substituted group to complete the design of new derivatives (Table 1).

In order to identify novel scaffolds for molecular recognition in kinases, we selected some compounds to be screened in a panel of kinases using the differential scanning fluorimetry (DSF) method $[35,36]$ at SGC-Unicamp. This technique allows selectivity profiling of any protein kinase without prior knowledge of either substrate or activity of the kinase under investigation. The most promising results were obtained for the CAMK1G calcium/calmodulin dependent protein kinase I gamma and for AAK1 AP2-associated protein kinase 1, as depicted in Figure 5, showing Tm shifts greater than $2{ }^{\circ} \mathrm{C}$. The pankinase inhibitor staurosporine (stauro) served as a positive control in the assay.

Table 1. $N$-arylamine oxetanes obtained via Buchwald-Hartwig Reaction.

Entry


Table 1. Cont.

\begin{tabular}{|c|c|c|c|c|}
\hline Entry & Halide/Triflate & Product & & Yield (\%) ${ }^{a}$ \\
\hline 3 & & & $\begin{array}{l}\text { 18a: } W=H \\
\text { 18b: } W=2,4-d i-F \\
\text { 18c: } W=2-C_{3} \\
\text { 18d: } W=2-\mathrm{OCH}_{3}\end{array}$ & $\begin{array}{l}71 \\
76 \\
95 \\
80\end{array}$ \\
\hline 4 & & & $\begin{array}{l}\text { 19a: } W=H \\
\text { 19b: } W=2,4-d i-F \\
\text { 19c: } W=2-C_{3} \\
\text { 19d: } W=2-\mathrm{OCH}_{3}\end{array}$ & $\begin{array}{l}83 \\
71 \\
88 \\
81\end{array}$ \\
\hline $5^{b}$ & & & $\begin{array}{l}\text { 20a: } W=H \\
\text { 20b: } W=2,4-d i-F \\
\text { 20c: } W=4-C_{3} \\
\text { 20d: } W=4-O C H_{3} \\
\text { 20e: } W=4-C N\end{array}$ & $\begin{array}{l}85 \\
66 \\
71 \\
54 \\
70\end{array}$ \\
\hline
\end{tabular}

${ }^{\mathrm{a}}$ Isolated yields after purification by column chromatography. ${ }^{\mathrm{b}}$ Products obtained after deprotection of benzyl ether group.

4-(3-phenyloxetan-3-yl)phenol derivatives 20c and 20e showed a $\Delta \mathrm{Tm}$ of $5.8^{\circ} \mathrm{C}$ and $5.2{ }^{\circ} \mathrm{C}$ at $10 \mu \mathrm{M}$, respectively against CAMK1G (Figure 6). These results suggest that electron-withdrawing groups on the aryl ring are well tolerated, in which the $4-\mathrm{CF}_{3}$ and $4-\mathrm{CN}$ analogs showed similar values. However, both an electron-donating group like 4-OCH 3 (20d) and the group 2,4-difluoryl (20b) were detrimental to CAMK1G interaction. Calcium-calmodulin dependent protein kinase I (CaMKI) is part of a calmodulin-dependent protein kinase cascade and is implicated in various physiological processes, being expressed in many tissues. CaMKI regulates transcriptional activator activity, the cell cycle, cell differentiation, actin filament organization and neurite outgrowth [37]. However, the role of CAMK1G is still mainly unclear.

Compounds 20c and $19 \mathrm{~b}$ showed a $\Delta \operatorname{Tm}$ of $5.2^{\circ} \mathrm{C}$ and $4.5^{\circ} \mathrm{C}$, respectively against AAK1 (Figure 7). Adaptor-associated kinase 1 (AAK1), a member of Ark1/Prk1 family of serine/threonine kinases, is involved in the endocytic pathway. Although AAK1 has been mostly related to the regulation of receptor endocytosis, several studies suggested that AAK1 may be associated to psychiatric and neurological disorders [38]. Recently, Kostich and co-workers have showed that the inhibition of AAK1 kinase could be a novel therapeutic approach for the treatment of neuropathic pain [39]. The inhibition of AAK1 also showed to be important as an antivirus strategy, especially against HCV [40,41]. In addition to these preliminary results, new structural modifications and experiments to measure the $\mathrm{K}_{\mathrm{d}}$ and $\mathrm{IC}_{50}$ will be carried out for a better understanding of the structure-activity relationship. 


\begin{tabular}{|c|c|c|c|c|c|c|c|c|c|c|}
\hline \multirow[t]{2}{*}{ Kinases } & \multicolumn{10}{|c|}{ Compounds } \\
\hline & $16 b$ & $20 b$ & 20d & $20 c$ & $20 e$ & $19 b$ & $17 b$ & $18 b$ & stauro & DMSO \\
\hline AAK1 & 2.78 & 2.12 & 0.11 & 5.20 & 2.60 & 4.54 & 2.65 & 1.69 & 8.13 & 0.00 \\
\hline BMP2K & 0.80 & 0.29 & 0.01 & 1.19 & 0.47 & 0.39 & 0.37 & 0.28 & 7.34 & 0.00 \\
\hline BMX & -0.23 & -0.36 & 0.00 & 0.47 & 0.23 & 0.13 & 0.18 & 0.56 & 4.26 & 0.00 \\
\hline BRAF & 0.23 & 0.23 & 0.22 & & 0.26 & 0.15 & 0.15 & 0.24 & -0.02 & 0.00 \\
\hline CAMK1D & -1.49 & -1.62 & -1.60 & -1.41 & -1.93 & 0.41 & -0.38 & -0.63 & 3.71 & 0.00 \\
\hline CAMK1G & -0.40 & 1.24 & 1.24 & 5.82 & 5.23 & 1.19 & 1.14 & 0.94 & 4.98 & 0.00 \\
\hline САМКК1 & -1.87 & -1.69 & -2.07 & -1.81 & -1.93 & -1.56 & & -0.68 & 5.35 & 0.00 \\
\hline САМКК2 & -0.25 & -0.09 & -0.22 & 1.82 & 0.33 & 0.56 & 0.54 & 0.06 & 15.90 & 0.00 \\
\hline CDC42BPA & 0.29 & -0.22 & -0.20 & -0.13 & 0.26 & 0.14 & 0.02 & 0.14 & 0.92 & 0.00 \\
\hline CDK2 & 2.20 & 2.10 & 2.20 & 2.53 & 1.97 & 1.95 & 2.21 & 2.35 & 6.99 & 0.00 \\
\hline CDKL1 & 0.22 & 0.31 & 0.26 & 0.23 & 0.15 & 0.62 & 0.07 & 0.33 & 0.93 & 0.00 \\
\hline CHEK2 & -0.06 & -0.61 & -0.29 & 0.48 & -0.49 & -0.26 & 0.29 & 0.11 & 0.87 & 0.00 \\
\hline CLK1 & 0.21 & -0.36 & -0.30 & 2.00 & -0.10 & -0.37 & 0.01 & 0.19 & 6.36 & 0.00 \\
\hline CSNK1G1 & 0.63 & 0.60 & 0.74 & 0.44 & 0.46 & 0.37 & 0.22 & 0.62 & 0.23 & 0.00 \\
\hline CSNK1G3 & -0.38 & -0.37 & -0.07 & -0.07 & -0.35 & -0.07 & 0.03 & -0.10 & 0.04 & 0.00 \\
\hline CSNK2A1 & 0.26 & 0.27 & 0.24 & 0.22 & 0.29 & 0.31 & 0.08 & 0.55 & 0.26 & 0.00 \\
\hline DYRK1 & -1.06 & -1.24 & -0.78 & -1.59 & -1.14 & -0.50 & -0.41 & -0.65 & 2.20 & 0.00 \\
\hline DYRK2 & 0.24 & 0.35 & 0.45 & 0.65 & 0.22 & 0.19 & 0.32 & 0.34 & 1.23 & 0.00 \\
\hline EPHA2 & -0.21 & -0.14 & -0.08 & 0.40 & -0.05 & -0.42 & -0.39 & -0.16 & 1.79 & 0.00 \\
\hline GAK & -0.99 & -1.21 & -1.47 & -1.51 & -1.22 & -0.82 & -0.30 & -0.82 & 3.68 & 0.00 \\
\hline GSG2 & 0.08 & 0.12 & -0.38 & -13.16 & -6.62 & 0.21 & -0.33 & 0.16 & 4.57 & 0.00 \\
\hline MAPK1 & -0.51 & -0.33 & -0.66 & -0.33 & -0.29 & -0.46 & -0.30 & -0.32 & -0.21 & 0.00 \\
\hline MAPK14B & -0.13 & -0.68 & -1.28 & -0.38 & -0.82 & -0.66 & -0.26 & -0.50 & -0.63 & 0.00 \\
\hline MAPK3 & 0.50 & 0.03 & -0.53 & 0.41 & -0.28 & -0.10 & -0.31 & 0.23 & 1.14 & 0.00 \\
\hline PHKG2A & 0.34 & 0.94 & 0.84 & 1.72 & 1.37 & 1.16 & 1.30 & 0.76 & 16.68 & 0.00 \\
\hline PIM1 & -0.27 & -0.72 & -1.41 & 0.24 & -0.41 & -0.53 & -0.86 & -0.60 & 4.67 & 0.00 \\
\hline PKMYT1A & -2.48 & -2.17 & -1.63 & -1.46 & -1.50 & -1.28 & -1.01 & -1.48 & -0.01 & 0.00 \\
\hline PRPF4B & -0.97 & -0.41 & -0.21 & 0.28 & -0.30 & -0.57 & -0.56 & 0.00 & 0.12 & 0.00 \\
\hline RPS6KA1A & -1.20 & -1.21 & -0.46 & -1.53 & -0.24 & -0.39 & 0.05 & -0.91 & -0.12 & 0.00 \\
\hline RPS6KA5A & -0.70 & -0.96 & -0.85 & -2.20 & -1.34 & 0.20 & -0.14 & -0.70 & 3.74 & 0.00 \\
\hline RPS6KA6A & -3.26 & -3.90 & -1.70 & -4.42 & 0.06 & -2.54 & -2.60 & -2.75 & 8.94 & 0.00 \\
\hline SLK & -1.85 & -2.98 & -1.85 & -0.57 & & -2.06 & 0.09 & -1.74 & 15.03 & 0.00 \\
\hline SRPK1 & -0.55 & -0.92 & -0.66 & -0.97 & & -0.12 & -0.60 & -0.71 & 2.31 & 0.00 \\
\hline SRPK2 & -0.77 & -1.09 & -0.79 & -1.42 & -1.08 & -0.41 & -0.63 & -0.57 & 0.10 & 0.00 \\
\hline STK3 & -0.24 & -0.66 & -0.65 & & -0.51 & 0.29 & -0.47 & 0.09 & 0.67 & 0.00 \\
\hline STK6 & 0.06 & 0.25 & -0.71 & 0.24 & & -0.24 & -0.82 & 0.01 & 11.88 & 0.00 \\
\hline STK10 & -0.11 & -1.19 & -0.51 & & & -0.31 & 0.53 & 0.20 & 22.26 & 0.00 \\
\hline STK38 & -0.75 & -0.22 & -0.26 & 0.69 & 0.25 & 0.53 & -0.01 & 0.03 & 5.12 & 0.00 \\
\hline TRIB2 & -0.69 & -0.74 & -3.36 & -1.69 & -0.89 & -0.49 & -1.46 & -0.98 & -0.41 & 0.00 \\
\hline TTKA & -1.53 & -1.12 & -1.20 & & & -0.70 & -0.76 & -0.06 & 1.68 & 0.00 \\
\hline WNK3 & -0.59 & -0.31 & -0.25 & -0.60 & -0.42 & -0.28 & -0.25 & -0.97 & -0.46 & 0.00 \\
\hline VRK1 & 0.76 & & -0.20 & 0.08 & 0.38 & -0.34 & 0.41 & 1.43 & 0.58 & 0.00 \\
\hline VRK2 & -0.36 & -1.32 & -1.36 & -2.29 & 1.17 & -1.28 & -0.75 & 0.05 & 0.92 & 0.00 \\
\hline
\end{tabular}

Figure 5. Results obtained from a kinase panel using differential scanning fluorimetry (DSF). 
<smiles>Oc1ccc(C2(c3ccc(Nc4ccc(C(F)(F)F)cc4)cc3)COC2)cc1</smiles>

20c<smiles>N#Cc1ccc(Nc2ccc(C3(c4ccc(O)cc4)COC3)cc2)cc1</smiles>

20e

$\Delta \mathrm{T}_{\mathrm{m}}$ САМK $1 \gamma=5.2^{\circ} \mathrm{C}$

Figure 6. $\triangle \mathrm{Tm}$ values obtained for the CAMK1G calcium/calmodulin dependent protein kinase I gamma.<smiles>Oc1ccc(C2(c3ccc(Nc4ccc(C(F)(F)F)cc4)cc3)COC2)cc1</smiles>

$20 \mathrm{c}$

$\Delta \mathrm{T}_{\mathrm{m}} \mathrm{AAK1}=5.2^{\circ} \mathrm{C}$<smiles>CC1(c2ccc(Nc3ccc(F)cc3F)cc2)COC1</smiles>

19b

$\Delta \mathrm{T}_{\mathrm{m}} \mathrm{AAK1}=4.5^{\circ} \mathrm{C}$

Figure 7. $\triangle \mathrm{Tm}$ values obtained for the AAK1 AP2-associated protein kinase 1.

\section{Materials and Methods}

All commercially available reagents and solvents were used without further purification. ${ }^{1} \mathrm{H}$ and ${ }^{13} \mathrm{C}$ nuclear magnetic resonance (NMR) spectra were determined in DMSO- $\mathrm{d}_{6}, \mathrm{CDCl}_{3}$ and Acetone- $\mathrm{d}_{6}$ solutions using a Bruker Avance $200\left({ }^{1} \mathrm{H}=200 \mathrm{MHz} ;{ }^{13} \mathrm{C}=50 \mathrm{MHz}\right)$ or a Bruker Avance $400\left({ }^{1} \mathrm{H}=400 \mathrm{MHz} ;{ }^{13} \mathrm{C}=100 \mathrm{MHz}\right)$ spectrometer. The chemical shifts are given in parts per million ( $\mathrm{ppm}$ ) from solvent residual peaks and the coupling constant values $(J)$ are given in Hz. Signal multiplicities are represented by: s (singlet), d (doublet), dd (double doublet), $t$ (triplet), $\mathrm{m}$ (multiplet) and br (broad signal). The evaluation of spectra was performed using the MestReNova program. Infrared spectra were obtained using a Thermo Scientific Nicolet's Avatar iS10 spectrometer equipped with a smart endurance diamond ATR unit for direct measurements. ESI mass spectra were obtained from a TLC-MS interface CAMAG in negative mode $\left[\mathrm{M}-\mathrm{H}^{+}\right]$. EI-MS mass spectra were obtained from the Mass Spectrometry Department of the Institute of Organic Chemistry, University of Tübingen: Finnigan MAT, TSQ 70 Tripel quadrupol; ion source temperature at $200{ }^{\circ} \mathrm{C}$; temperature of evaporation: $30-300{ }^{\circ} \mathrm{C}$; ionization energy: $70 \mathrm{eV}$. The compounds were purified through column chromatography, using silica gel as stationary phase (Geduran ${ }^{\circledR}$ Si $60,0.063-0.200 \mathrm{~mm}$ ). The purity of compounds was determined by HPLC (Merck Hitachi L-6200 intelligent pump, Merck Hitachi AS-2000 auto sampler, Merck Hitachi L-4250 UV vis detector) using a ZORBAX Eclipse XDB C8 column (5 mm), employing a gradient of $0.01 \mathrm{M} \mathrm{KH}_{2} \mathrm{PO}_{4}(\mathrm{pH} 2.3)$ and methanol as solvent system with a flow rate of $1.5 \mathrm{~mL} / \mathrm{min}$ and detection at $254 \mathrm{~nm}$.

Kinase selectivity assay: Starting from $100 \mu \mathrm{M}$ protein stocks, all the kinases present in the panel were diluted to $1 \mu \mathrm{M}$ in buffer $100 \mathrm{mM} \mathrm{K}_{2} \mathrm{HPO}_{4} \mathrm{pH} 7.5$ containing $150 \mathrm{mM} \mathrm{NaCl}, 10 \%$ glycerol and $1 \mathrm{X}$ dye (Applied Biosystems catalog 4461806). The protein/dye mixture was transferred column-wise to a 384-well PCR microplate with $20 \mu \mathrm{L}$ per well. Compounds at $10 \mathrm{mM}$ concentration in DMSO (from a separate plate arranged in rows) were added next, in $20 \mathrm{~nL}$ volume, using a liquid handling device setup with a pin head to make a final $10 \mu \mathrm{M}$ compound in the assay plate. The final DMSO concentration in all wells is $0.2 \%$, including the reference with DMSO only. Thermal shift data was measured in a qPCR instrument (Applied Biosystems QuantStudio 6) programmed to equilibrate the plate at $25^{\circ} \mathrm{C}$ for $5 \mathrm{~min}$ followed by ramping the temperature to $95^{\circ} \mathrm{C}$ at a rate of $0.05^{\circ} \mathrm{C}$ per second. Data was processed on Protein Thermal shift software (Applied Biosystems) fitting experimental curves to a Boltzmann function to calculate differential thermal shifts (dTm) referenced to protein/dye 
in $0.2 \%$ DMSO. The kinases were cloned, expressed (bacteria or insect cell expression) and purified at the laboratory of SGC.

\subsection{General Procedure A-Corey-Chaykovsky Epoxidation}

4.0 eq. of $\mathrm{NaH}$ (60\% dispersion in mineral oil) was placed in a three-necked flask under argon and then DMSO $(0.6 \mathrm{M})$ and the ketone were added, after which 2.25 eq. of trimethylsulfonium iodide was also added, all at once. The reaction mixture was stirred at ambient temperature. After controlling through TLC, the mixture was poured over ice and extracted with diethyl ether and ethyl acetate (1:1). The extracts were combined, washed with brine and afterwards dried over $\mathrm{Na}_{2} \mathrm{SO}_{4}$. The solvent was removed under vacuum, and the residue was used without purification for the next step. Adapted from Winter [19].

2-bromo-6,7,8,9-tetrahydrospiro[benzo[7]annulene-5,2'-oxirane](2a): Yellow oil. 95\% yield. ${ }^{1} \mathrm{H}-\mathrm{NMR}(200 \mathrm{MHz}$, $\left.\mathrm{CDCl}_{3}\right) \delta$ in ppm: $1.62-1.80(\mathrm{~m}, 2 \mathrm{H}), 1.80-2.15(\mathrm{~m}, 2 \mathrm{H}), 2.74(\mathrm{~d}, 1 \mathrm{H}, J=6.0 \mathrm{~Hz}), 2.82-2.87(\mathrm{~m}, 2 \mathrm{H})$, $2.98(\mathrm{~d}, 1 \mathrm{H}, J=6.0 \mathrm{~Hz}), 7.30(\mathrm{~m}, 3 \mathrm{H}) ;{ }^{13} \mathrm{C}-\mathrm{NMR}\left(50 \mathrm{MHz}, \mathrm{CDCl}_{3}\right) \delta$ in ppm: 27.0, 28.6, 35.9, 36.0, 53.9, 60.8, $121.2,126.9,129.1,131.8,140.1,143.3$.

6-bromo-3,4-dihydro-2H-spiro[naphthalene-1,2'-oxirane] (2b): Yellow solid. 90\% yield. ${ }^{1} \mathrm{H}-\mathrm{NMR}(200 \mathrm{MHz}$, $\left.\mathrm{CDCl}_{3}\right) \delta$ in ppm: 1.75-1.85 (m, 2H), 2.06-2.11 (m, 2H), 2.83-2.87 (m, 2H), $2.97(\mathrm{~s}, 2 \mathrm{H}), 6.92-6.96(\mathrm{~d}, 2 \mathrm{H})$, 7.27-7.29 (s, 1H); ${ }^{13} \mathrm{C}-\mathrm{NMR}\left(50 \mathrm{MHz}, \mathrm{CDCl}_{3}\right) \delta$ in ppm: 21.9, 29.6, 31.7, 56.4, 58.9, 121.5, 125.4, 129.6, $131.4,134.9,141.7$.

2-(4-bromophenyl)-2-methyloxirane (2c): Yellow solid. 90\% yield. ${ }^{1} \mathrm{H}-\mathrm{NMR}\left(200 \mathrm{MHz}, \mathrm{CDCl}_{3}\right) \delta$ in ppm: $1.70(\mathrm{~s}, 3 \mathrm{H}), 2.74-2.77(\mathrm{~d}, 1 \mathrm{H}), 2.97-2.99(\mathrm{~d}, 1 \mathrm{H}), 7.22-7.26(\mathrm{~d}, J=8.0 \mathrm{~Hz}, 2 \mathrm{H}), 7.44-7.48(\mathrm{~d}, J=8.0 \mathrm{~Hz}$, $2 \mathrm{H}) ;{ }^{13} \mathrm{C}-\mathrm{NMR}\left(50 \mathrm{MHz}, \mathrm{CDCl}_{3}\right) \delta$ in ppm: 21.7, 56.5, 57.1, 121.6, 127.2, 131.6, 140.4 .

\subsection{General Procedure B-Meinwald Rearrangement}

The crude epoxide was dissolved in benzene $(0.3 \mathrm{M})$ and 0.3 eq. of $\mathrm{ZnI}_{2}$ was added; the reaction mixture was heated at reflux under argon. After controlling through TLC, it was then diluted with ethyl acetate and washed with water. The organic layer was dried with $\mathrm{Na}_{2} \mathrm{SO}_{4}$, and the solvent was evaporated to afford the pure aldehyde, which was used without purification for the next step. Adapted from Snyder et al. [20].

2-bromo-6,7,8,9-tetrahydro-5H-benzo[7]annulene-5-carbaldehyde (3a): Brown oil. 98\% yield. ${ }^{1} \mathrm{H}-\mathrm{NMR}(200 \mathrm{MHz}$, $\left.\mathrm{CDCl}_{3}\right) \delta$ in ppm: 1.59-2.25 (m, 6H, $\left.\mathrm{CH}_{2}\right), 2.68\left(\mathrm{t}, 2 \mathrm{H}, \mathrm{CH}_{2}\right), 3.71(\mathrm{~d}, 1 \mathrm{H}, \mathrm{CH}), 6.95(\mathrm{~d}, 1 \mathrm{H}, \mathrm{J}=8.0 \mathrm{~Hz})$, $7.31(\mathrm{~m}, 2 \mathrm{H}), 9.89(\mathrm{~s}, 1 \mathrm{H})$.

6-bromo-1,2,3,4-tetrahydronaphthalene-1-carbaldehyde (3b): Brown oil. 95\% yield. ${ }^{1} \mathrm{H}-\mathrm{NMR}(200 \mathrm{MHz}$, $\left.\mathrm{CDCl}_{3}\right) \delta$ in ppm: $1.92(\mathrm{~m}, 2 \mathrm{H}), 2.24(\mathrm{~m}, 2 \mathrm{H}), 2.72-2.78(\mathrm{t}, 2 \mathrm{H}), 3.58(\mathrm{t}, 1 \mathrm{H}), 6.99-7.03(\mathrm{~d}, 1 \mathrm{H})$, 7.30-7.34 (m, 2H), $9.64(\mathrm{~s}, 1 \mathrm{H}) ;{ }^{13} \mathrm{C}-\mathrm{NMR}\left(50 \mathrm{MHz}, \mathrm{CDCl}_{3}\right) \delta$ in ppm: 20.2, 22.9, 29.1, 51.3, 121.2, 129.4, $129.9,131.3,132.6,140.3,201.4$.

2-(4-bromophenyl)propanal (3c): Brown oil. 98\% yield. ${ }^{1} \mathrm{H}-\mathrm{NMR}\left(200 \mathrm{MHz}, \mathrm{CDCl}_{3}\right) \delta$ in ppm: $1.41-1.45(\mathrm{~d}, 3 \mathrm{H})$, 3.55-3.66 (q, 1H), 7.06-7.11 (d, 2H), 7.48-7.52 (d, 2H), $9.65(\mathrm{~s}, 1 \mathrm{H}) ;{ }^{13} \mathrm{C}-\mathrm{NMR}\left(50 \mathrm{MHz}, \mathrm{CDCl}_{3}\right) \delta$ in ppm: $14.7,52.5,121.7,130.1,132.3,136.8,200.5$.

\subsection{General Procedure C-Crossed Cannizzaro Reaction}

A mixture of $35 \%$ formalin, $\mathrm{KOH} 50 \%$ aqueous solution and the aldehyde in ethylene glycol $(0.4 \mathrm{M})$ was heated at reflux overnight. Water was added to the resulting mixture, and the organic layer was extracted with $\mathrm{CH}_{2} \mathrm{Cl}_{2}$, washed with brine, and dried over $\mathrm{Na}_{2} \mathrm{SO}_{4}$. After concentration of the solution, hexane was added immediately with vigorous stirring, and then the mixture was cooled to $0^{\circ} \mathrm{C}$. White precipitate was collected, washed with hexane, and dried under air to obtain the diol. Adapted from Sato et al. [21]. 
(2-bromo-6,7,8,9-tetrahydro-5H-benzo[7]annulene-5,5-diyl)dimethanol (4a): White solid. 61\% yield. HPLC: $6.948 \mathrm{~min}(83 \%)$ at $254 \mathrm{~nm}$. IR (ATR): 3276, 2931, 2882, 2855, 1556, $1445 \mathrm{~cm}^{-1}$. ESI-MS: Calculated: 284.0 for $\mathrm{C}_{13} \mathrm{H}_{17} \mathrm{BrO}_{2}$. Found: $283[\mathrm{M}-\mathrm{H}]^{-} .{ }^{1} \mathrm{H}-\mathrm{NMR}\left(200 \mathrm{MHz}, \mathrm{CDCl}_{3}\right) \delta$ in ppm: $1.26\left(\mathrm{~s}, 2 \mathrm{H}, \mathrm{CH}_{2}\right)$, $1.79\left(\mathrm{~m}, 4 \mathrm{H}, \mathrm{CH}_{2}\right), 2.31\left(\mathrm{~s}, 2 \mathrm{H}, \mathrm{CH}_{2}\right), 2.90(\mathrm{br}, 2 \mathrm{H}), 3.88(\mathrm{~d}, 2 \mathrm{H}, J=10 \mathrm{~Hz}), 4.04(\mathrm{~d}, 2 \mathrm{H}, J=12 \mathrm{~Hz})$, 7.27-7.30 (m, 3H); ${ }^{13} \mathrm{C}-\mathrm{NMR}\left(50 \mathrm{MHz}, \mathrm{CDCl}_{3}\right) \delta$ in ppm: 23.9, 27.3, 30.9, 35.9, 48.6, 68.5, 120.7, 129.3, $129.9,134.4,140.2,144.8$.

(6-bromo-1,2,3,4-tetrahydronaphthalene-1,1-diyl)dimethanol (4b): White solid. 45\% yield. HPLC: $6.950 \mathrm{~min}$ (96\%). IR (ATR): 3269, 2928, 2868, 2360, $1479 \mathrm{~cm}^{-1}$. ESI-MS: Calculated: 270.03 for $\mathrm{C}_{12} \mathrm{H}_{15} \mathrm{BrO}_{2}$. Found: $269[\mathrm{M}-\mathrm{H}]^{-} .{ }^{1} \mathrm{H}-\mathrm{NMR}\left(200 \mathrm{MHz}, \mathrm{CDCl}_{3}\right) \delta$ in ppm: $1.77-1.92(\mathrm{~m}, 4 \mathrm{H}), 1.93(\mathrm{~s}, 2 \mathrm{H}), 2.72-2.78$ $(\mathrm{t}, 2 \mathrm{H}), 3.71-3.76(\mathrm{~d}, 2 \mathrm{H}, J=10 \mathrm{~Hz}), 3.87-3.92(\mathrm{~d}, 2 \mathrm{H}, J=10 \mathrm{~Hz}), 7.27(\mathrm{~s}, 3 \mathrm{H}) ;{ }^{13} \mathrm{C}-\mathrm{NMR}\left(50 \mathrm{MHz}, \mathrm{CDCl}_{3}\right)$ $\delta$ in ppm: $18.9,27.7,30.5,43.3,69.7,120.6,128.9,129.2,132.4,136.9,141.2$.

(5-chloro-2,3-dihydro-1H-indene-1,1-diyl)dimethanol (10): White solid. 30\% yield. HPLC: $5.580 \mathrm{~min}$ (98\%). IR (ATR): 3280, 2933, 2877, 2843, 1451, 1200, $824 \mathrm{~cm}^{-1}$. ESI-MS: Calculated: 212.0 for $\mathrm{C}_{11} \mathrm{H}_{13} \mathrm{ClO}_{2}$. Found: $211[\mathrm{M}-\mathrm{H}]^{-} .{ }^{1} \mathrm{H}-\mathrm{NMR}\left(200 \mathrm{MHz}, \mathrm{CDCl}_{3}\right) \delta$ in ppm: $2.04-2.12(\mathrm{~m}, 4 \mathrm{H}), 2.88-2.96(\mathrm{t}, 2 \mathrm{H})$, 3.72-3.87 (q, 4H), 7.12-7.25 (m, 3H); ${ }^{13} \mathrm{C}-\mathrm{NMR}\left(50 \mathrm{MHz}, \mathrm{CDCl}_{3}\right) \delta$ in ppm: 30.2, 31.4, 54.2, 68.2, 125.2, $125.4,126.8,133.6,143.2,146.8$.

2-(4-bromophenyl)-2-methylpropane-1,3-diol (4c): White solid. 67\% yield. HPLC: $5.280 \mathrm{~min}$ (100\%). ESI-MS: Calculated: 244.01/246.01 for $\mathrm{C}_{10} \mathrm{H}_{13} \mathrm{BrO}_{2}$. Found: $243 / 245[\mathrm{M}-\mathrm{H}]^{-}$. ${ }^{1} \mathrm{H}-\mathrm{NMR}(200 \mathrm{MHz}$, $\left.\mathrm{CDCl}_{3}\right) \delta$ in ppm: $1.25(\mathrm{~s}, 3 \mathrm{H}), 2.22(\mathrm{~s}, 2 \mathrm{H}), 3.78-3.83(\mathrm{~d}, 2 \mathrm{H}), 3.91-3.97(\mathrm{~d}, 2 \mathrm{H}), 7.29-7.33(\mathrm{~d}, 2 \mathrm{H})$, 7.46-7.51 (d, 2H); ${ }^{13} \mathrm{C}-\mathrm{NMR}\left(50 \mathrm{MHz}, \mathrm{CDCl}_{3}\right) \delta$ in ppm: 20.9, 44.5, 70.0, 120.8, 128.7, 131.8, 142.3 .

\subsection{General Procedure D—Wittig Reaction}

Methyltriphenylphosphonium bromide $(1.287 \mathrm{~g}, 3.601 \mathrm{mmol})$ was suspended in $15 \mathrm{~mL}$ of dry THF at $0{ }^{\circ} \mathrm{C}$. $\mathrm{KOtBu}(0.404 \mathrm{~g}, 3.601 \mathrm{mmol})$ was added to the suspension and a bright yellow color was observed. The mixture was stirred at $0{ }^{\circ} \mathrm{C}$ for $30 \mathrm{~min}$. Then 5-chloro-2,3-dihydro-1H-inden-1-one $(0.200 \mathrm{~g}, 1.200 \mathrm{mmol})$ was added neat and the reaction mixture was stirred at $0{ }^{\circ} \mathrm{C}$ to r.t. for $4 \mathrm{~h}$ (the solution turned green and then dark brown). Water was added to the mixture and the product was extracted with $\mathrm{CH}_{2} \mathrm{Cl}_{2}$ and dried with $\mathrm{Na}_{2} \mathrm{SO}_{4}$, filtrated and concentrated in vacuum. The residue was purified by column chromatography using $n$-hexane. Adapted from Liwosz and Chemler [24].

5-chloro-1-methylene-2,3-dihydro-1H-indene (7): Incolor oil. 83\% yield. HPLC: 9.720 min (99.4\%). ${ }^{1} \mathrm{H}-\mathrm{NMR}\left(200 \mathrm{MHz}, \mathrm{CDCl}_{3}\right) \delta$ in ppm: $2.77-2.85(\mathrm{~m}, 2 \mathrm{H}), 2.93-3.00(\mathrm{~m}, 2 \mathrm{H}), 5.04-5.07(\mathrm{t}, 1 \mathrm{H})$, $5.42-5.44(\mathrm{t}, 1 \mathrm{H}), 7.15-7.19(\mathrm{~d}, J=8.0 \mathrm{~Hz}, 1 \mathrm{H}), 7.23(\mathrm{~s}, 1 \mathrm{H}), 7.38-7.42(\mathrm{~d}, J=8.0 \mathrm{~Hz}, 1 \mathrm{H}) ;{ }^{13} \mathrm{C}-\mathrm{NMR}(50 \mathrm{MHz}$, $\left.\mathrm{CDCl}_{3}\right) \delta$ in ppm: $13.1,37.6,119.7,124.1,126.3,129.2,130.7,139.5,144.8,146.1$.

\subsection{General Procedure E-Brown Hydroboration-Oxidation}

A solution of $1.6 \mathrm{~g}$ (9.537 mmol) of 5-chloro-1-methylene-2,3-dihydro-1H-indene in $10 \mathrm{~mL}$ of THF was treated with a solution of $19.0 \mathrm{~mL}$ of $\mathrm{BH}_{3}$ - THF complex at ice-bath temperature. The reaction mixture was stirred until disappearance of the alkene. It was then cooled in a water-ice bath, and carefully treated with methanol followed by addition of $31.8 \mathrm{~mL}(95.365 \mathrm{mmol})$ of $\mathrm{NaOH} 3.0 \mathrm{M}$ and $25.3 \mathrm{~mL}$ ( $247.959 \mathrm{mmol})$ of $30 \% \mathrm{H}_{2} \mathrm{O}_{2}$. The resulting mixture was stirred at room temperature, poured into water, acidified with $10 \% \mathrm{HCl}$, and extracted with ether. The organic layer was dried with $\mathrm{Na}_{2} \mathrm{SO}_{4}$ and the solvent was evaporated to afford the pure alcohol after purification by column in silica gel (20\% EtOAc: $n$-hexane). Adapted from Zimmerman and Nesterov [26].

(5-chloro-2,3-dihydro-1H-inden-1-yl)methanol (8): Yellow oil. 80\% yield. HPLC: 9.720 min (99.4\%). IR (ATR): $3323,2940,2866,1598,1471,1067,870 \mathrm{~cm}^{-1} .{ }^{1} \mathrm{H}-\mathrm{NMR}\left(400 \mathrm{MHz}, \mathrm{CDCl}_{3}\right) \delta$ in ppm: 1.62 (br s, 1H), 1.91-1.98 (sextet, 1H), 2.23-2.32 (sextet, 1H), 2.82-2.99 (m, 2H), 3.27-3.34 (quintet, 1H), 3.76-3.77 (d, 2H), 7.13-7.15 (d, 1H), 7.19-7.21 (m, 2H); ${ }^{13} \mathrm{C}-\mathrm{NMR}\left(50 \mathrm{MHz}, \mathrm{CDCl}_{3}\right) \delta$ in ppm: 28.7, 31.4, $47.1,65.9,125.1,125.3,126.5,132.8,142.5,146.8$. 


\subsection{General Procedure F-Dess-Martin Reaction}

To a solution of $0.470 \mathrm{~g}$ (2.573 mmol) of (5-chloro-2,3-dihydro-1H-inden-1-yl)methanol in $20 \mathrm{~mL}$ of $\mathrm{CH}_{2} \mathrm{Cl}_{2}(0.13 \mathrm{M}) 1.6 \mathrm{~g}$ (3.860 mmol) of Dess-Martin periodate was added. The reaction was allowed to stir at room temperature for $3 \mathrm{~h}$. TLC and HPLC analysis showed formation of the desired product. The solution was diluted with $\mathrm{CH}_{2} \mathrm{Cl}_{2}$ and a $10 \% \mathrm{Na}_{2} \mathrm{~S}_{2} \mathrm{O}_{3}$ solution to consume the excess Dess-Martin reagent was added. The mixture was stirred until the two layers separated. The $\mathrm{CH}_{2} \mathrm{Cl}_{2}$ layer was collected, washed with saturated $\mathrm{Na}_{2} \mathrm{CO}_{3}$ solution and dried with $\mathrm{Na}_{2} \mathrm{SO}_{4}$, filtered and evaporated to give the crude aldehyde, which was used in the next step without purification. Adapted from Thongsornkleeb and Danheiser [27].

5-chloro-2,3-dihydro-1H-indene-1-carbaldehyde (9): Yellow oil. 98\% yield. ${ }^{1} \mathrm{H}-\mathrm{NMR}\left(200 \mathrm{MHz}, \mathrm{CDCl}_{3}\right) \delta$ in ppm: 2.36-2.45 (m, 2H), 2.95-3.03 (t, 2H), 3.88-3.95 (t, 1H), $7.20(\mathrm{~s}, 3 \mathrm{H}), 9.64(\mathrm{~s}, 1 \mathrm{H}) ;{ }^{13} \mathrm{C}-\mathrm{NMR}(50 \mathrm{MHz}$, $\left.\mathrm{CDCl}_{3}\right) \delta$ in ppm: $25.8,31.7,57.3,125.5,126.0,127.1,134.0,137.0,146.8,200.2$.

\subsection{General Procedure G-Nucleophilic Addition to the Carbonyl Group}

Compound 9 was synthesized according to General Procedure H: 2,6 mL (6.513 mmol) of $n$-BuLi was added dropwise over $5 \mathrm{~min}$ to a solution of $1.71 \mathrm{~g}(6.513 \mathrm{mmol})$ of 1-(benzyloxy)-4-bromobenzene in $20 \mathrm{~mL}$ of $\mathrm{THF}$ at $-78{ }^{\circ} \mathrm{C}$. The reaction mixture was stirred at $-78{ }^{\circ} \mathrm{C}$ for a further $30 \mathrm{~min}$. Then, $0.36 \mathrm{~g}(5.010 \mathrm{mmol})$ of oxetan-3-one was added dropwise to the reaction mixture. After a further $45 \mathrm{~min}$ at $-78^{\circ} \mathrm{C}$ the reaction mixture was warmed to room temperature then quenched with water. The layers were separated and the aqueous portion extracted with diethylether. The organic extracts were combined, washed with brine, dried over $\mathrm{Na}_{2} \mathrm{SO}_{4}$, filtered and concentrated in vacuum. Purification by column chromatography (40\% EtOAc: $n$-hexane) afforded the product. Adapted from Croft et al. [28].

3-(4-(benzyloxy)phenyl)oxetan-3-ol (13): White solid. 70\% yield. HPLC: $6.898 \mathrm{~min}(98 \%) .{ }^{1} \mathrm{H}-\mathrm{NMR}(400 \mathrm{MHz}$, $\left.\mathrm{CDCl}_{3}\right) \delta$ in ppm: $2.92(\mathrm{br}, 1 \mathrm{H}), 4.86-4.91(\mathrm{~m}, 4 \mathrm{H}), 5.09(\mathrm{~s}, 2 \mathrm{H}), 7.00-7.02(\mathrm{~d}, 2 \mathrm{H}, \mathrm{J}=8.0 \mathrm{~Hz}), 7.33-7.35$ $(\mathrm{d}, 2 \mathrm{H}, J=8.0 \mathrm{~Hz}), 7.38-7.45(\mathrm{~m}, 4 \mathrm{H}), 7.47-7.49(\mathrm{~d}, 2 \mathrm{H}, J=8.0 \mathrm{~Hz}) ;{ }^{13} \mathrm{C}-\mathrm{NMR}\left(100 \mathrm{MHz}, \mathrm{CDCl}_{3}\right) \delta$ in ppm: $70.2,75.8,85.7,115.2,126.1,127.6,128.2,128.8,134.9,136.9,158.6$.

\subsection{General Procedure H-Oxetane Formation via Williamson Etherification}

The diol was dissolved in THF $(0.1 \mathrm{M})$ and then 4 eq. of $\mathrm{CCl}_{4}$ was added. The solution was cooled to $-48{ }^{\circ} \mathrm{C}$ and then 1.1 eq. of Tris(dimethylamino)phosphine in $1 \mathrm{~mL}$ of THF was added slowly to this solution during $5 \mathrm{~min}$. The solution turned slightly turbid. The flask was transferred to an ice-bath and then agitated until it reached room temperature. After controlling using HPLC, the solvent was evaporated and then methanol was added followed by 4 eq. of a $5.4 \mathrm{M}$ solution of sodium methoxide. The mixture was refluxed at $90^{\circ} \mathrm{C}$ during $1 \mathrm{~h}$. The reaction was then diluted with ethyl acetate and washed with water. The organic layer was dried with $\mathrm{Na}_{2} \mathrm{SO}_{4}$ and the solvent was evaporated to afford a product after purification by column in silica gel ( $5 \%$ EtOAc: $n$-hexane). Adapted from Castro and Selve [23].

2-bromo-6,7,8,9-tetrahydrospiro[benzo[7]annulene-5,3'-oxetane] (5a): Yellow oil. 47\% yield. HPLC: 8.497 min (93\%). EI-MS: Calculated 266.03 for $\mathrm{C}_{13} \mathrm{H}_{15} \mathrm{BrO}$. Found: 235.9 [M-CH $\mathrm{CH}^{+\bullet}$. ${ }^{1} \mathrm{H}-\mathrm{NMR}(200 \mathrm{MHz}$, $\left.\mathrm{CDCl}_{3}\right) \delta$ in ppm: $1.53-1.59(\mathrm{t}, 2 \mathrm{H}), 1.99-2.01(\mathrm{t}, 2 \mathrm{H}), 2.12-2.15(\mathrm{~d}, 2 \mathrm{H}), 2.4-2.45(\mathrm{~d}, 2 \mathrm{H}), 4.70-4.73$ $(\mathrm{d}, J=6.0 \mathrm{~Hz}, 2 \mathrm{H}), 4.97-5.00(\mathrm{~d}, J=6.0 \mathrm{~Hz}, 2 \mathrm{H}), 6.92-6.96(\mathrm{~d}, 1 \mathrm{H}), 7.21-7.33(\mathrm{~m}, 2 \mathrm{H}) .{ }^{13} \mathrm{C}-\mathrm{NMR}(50 \mathrm{MHz}$, $\left.\mathrm{CDCl}_{3}\right) \delta$ in ppm: $26.4,26.9,34.9,36.5,47.9,80.4,120.0,129.2,132.5,143.4,144.4$.

6-bromo-3,4-dihydro-2H-spiro[naphthalene-1,3'-oxetane] (5b): Yellow oil. 48\% yield. HPLC: $8.230 \mathrm{~min}$ (98\%). EI-MS: Calculated 252.01 for $\mathrm{C}_{12} \mathrm{H}_{13} \mathrm{BrO}$. Found: 221.9 [M-CH $\mathrm{C}_{2}{ }^{+\bullet}$. ${ }^{1} \mathrm{H}-\mathrm{NMR}(200 \mathrm{MHz}$, $\left.\mathrm{CDCl}_{3}\right) \delta$ in ppm: 1.65-1.77 (m, 2H), 2.14-2.20 (t, 2H), 2.69-2.75 (t, 2H), 4.62-4.65 (d, J = 6.0 Hz, 2H), 4.75-4.78 (d, J = 6.0 Hz, 2H), 7.21-7.22 (s, 1H), 7.38-7.43 (d, 1H), 7.77-7.81 (d, 1H). ${ }^{13} \mathrm{C}-\mathrm{NMR}(50 \mathrm{MHz}$, $\left.\mathrm{CDCl}_{3}\right) \delta$ in ppm: $20.0,29.9,35.3,42.2,85.4,120.4,128.4,129.9,131.7,138.7,139.2$. 
5-chloro-2,3-dihydrospiro[indene-1,3'-oxetane] (11): Yellow oil. 47\% yield. HPLC: 7.664 min (97\%). EI-MS: Calculated 194.0 for $\mathrm{C}_{11} \mathrm{H}_{11} \mathrm{ClO}$. Found: $163.9\left[\mathrm{M}-\mathrm{CH}_{2} \mathrm{O}\right]^{+\bullet} \cdot{ }^{1} \mathrm{H}-\mathrm{NMR}\left(200 \mathrm{MHz}, \mathrm{CDCl}_{3}\right) \delta$ in ppm: $2.43-2.50(\mathrm{t}, J=6.0 \mathrm{~Hz}, 2 \mathrm{H}), 2.83-2.90(\mathrm{t}, J=6.0 \mathrm{~Hz}, 2 \mathrm{H}), 4.80(\mathrm{~s}, 4 \mathrm{H}), 7.17(\mathrm{~s}, 1 \mathrm{H}), 7.18-7.29(\mathrm{~d}, 1 \mathrm{H})$, 7.56-7.60 (d, 1H). ${ }^{13} \mathrm{C}-\mathrm{NMR}\left(50 \mathrm{MHz}, \mathrm{CDCl}_{3}\right) \delta$ in ppm: 30.4, 37.9, 50.9, 84.2, 123.8, 124.8, 127.4, 133.4, $144.7,145.4$.

3-(4-bromophenyl)-3-methyloxetane (5c): Yellow solid. 35\% yield. HPLC: $7.390 \mathrm{~min}(98 \%)$. EI-MS: Calculated 226.00 for $\mathrm{C}_{10} \mathrm{H}_{11} \mathrm{BrO}$. Found: $195.9\left[\mathrm{M}_{-} \mathrm{CH}_{2} \mathrm{O}\right]^{+\bullet} .{ }^{1} \mathrm{H}-\mathrm{NMR}\left(200 \mathrm{MHz}, \mathrm{CDCl}_{3}\right) \delta$ in ppm: $1.71(\mathrm{~s}, 3 \mathrm{H})$, $4.62-4.64(\mathrm{~d}, 2 \mathrm{H}), 4.90-4.93(\mathrm{~d}, 2 \mathrm{H}), 7.07-7.11(\mathrm{~d}, J=8.0 \mathrm{~Hz}, 2 \mathrm{H}), 7.46-7.50(\mathrm{~d}, J=8.0 \mathrm{~Hz}, 2 \mathrm{H}) .{ }^{13} \mathrm{C}-\mathrm{NMR}$ $\left(50 \mathrm{MHz}, \mathrm{CDCl}_{3}\right) \delta$ in ppm: 27.7, 43.3, 83.64, 120.3, 127.0, 131.8, 145.6.

\subsection{General Procedure I-Oxetane Formation via Friedel-Crafts Reaction}

Quantities of $0.008 \mathrm{~g}(0.028 \mathrm{mmol})$ of lithium bis(trifluoromethanesulfonimide) and $0.006 \mathrm{~g}$ $(0.014 \mathrm{mmol})$ of tetrabutylammonium hexafluorophosphate were added to a solution of $0.066 \mathrm{~g}$ ( $0.258 \mathrm{mmol})$ of 3-(4-(benzyloxy)phenyl)oxetan-3-ol and $0.12 \mathrm{~g}(1.288 \mathrm{mmol})$ of phenol in $0.5 \mathrm{~mL}$ of chloroform. The reaction mixture was stirred at $40{ }^{\circ} \mathrm{C}$ for $1 \mathrm{~h}$ then quenched with sat. aq. $\mathrm{NaHCO}_{3}$. $\mathrm{CH}_{2} \mathrm{Cl}_{2}$ was added and the layers were separated. The organic extracts were combined, dried over $\mathrm{Na}_{2} \mathrm{SO}_{4}$, filtered and concentrated in vacuum. Purification by column chromatography (30\% EtOAc: $n$-hexane) afforded the oxetane. Adapted from Croft et al. [28].

4-(3-(4-(benzyloxy)phenyl)oxetan-3-yl)phenol (14): White solid. 60\% yield. HPLC: 8.286 min (93\%). ESI-MS: Calculated: 332.14 for $\mathrm{C}_{22} \mathrm{H}_{20} \mathrm{O}_{3}$. Found: $331.1[\mathrm{M}-\mathrm{H}]^{-}$. ${ }^{1} \mathrm{H}-\mathrm{NMR}\left(200 \mathrm{MHz}, \mathrm{CDCl}_{3}\right) \delta$ in ppm: $5.06(\mathrm{~s}, 2 \mathrm{H}), 5.21(\mathrm{~s}, 4 \mathrm{H}), 6.78-6.82(\mathrm{~d}, J=8.0 \mathrm{~Hz}, 2 \mathrm{H}), 6.94-6.98(\mathrm{~d}, J=8.0 \mathrm{~Hz}, 2 \mathrm{H}), 7.05-7.15$ $(\mathrm{m}, 4 \mathrm{H}), 7.36-7.42(\mathrm{~m}, 5 \mathrm{H}) ;{ }^{13} \mathrm{C}-\mathrm{NMR}\left(50 \mathrm{MHz}, \mathrm{CDCl}_{3}\right) \delta$ in ppm: 50.5, 70.2, 85.2, 114.9, 115.5, 127.6, $127.8,127.9,128.2,128.8,137.1,138.3,138.5,154.4,157.6$.

\subsection{General Procedure J-Triflate Formation}

First, $0.2 \mathrm{~mL}(2.708 \mathrm{mmol})$ of pyridine, then $0.3 \mathrm{~mL}(2.031 \mathrm{mmol})$ of triflic anhydride were added to a solution of 4-(3-(4-(benzyloxy)phenyl)oxetan-3-yl)phenol in $3.0 \mathrm{~mL}$ of $\mathrm{CH}_{2} \mathrm{Cl}_{2}$. The reaction mixture was stirred at room temperature. After controlling through TLC and HPLC, the work-up was done adding water followed by $\mathrm{CH}_{2} \mathrm{Cl}_{2}$. The layers were separated and the aqueous portion was extracted with $\mathrm{CH}_{2} \mathrm{Cl}_{2}$. The organic extracts were combined, dried over $\mathrm{Na}_{2} \mathrm{SO}_{4}$, filtered and concentrated in vacuum. Purification by column chromatography ( $20 \%$ EtOAc: $n$-hexane) afforded the triflate. Adapted from Thompson et al. [30].

4-(3-(4-(benzyloxy)phenyl)oxetan-3-yl)phenyl trifluoromethanesulfonate (15): White solid. 90\% yield. HPLC: $10.332 \mathrm{~min}(100 \%)$. ESI-MS: Calculated: 464.09 for $\mathrm{C}_{23} \mathrm{H}_{19} \mathrm{~F}_{3} \mathrm{O}_{5} \mathrm{~S}$. Found: $463.0[\mathrm{M}-\mathrm{H}]^{-}$. ${ }^{1} \mathrm{H}-\mathrm{NMR}\left(200 \mathrm{MHz}, \mathrm{CDCl}_{3}\right) \delta$ in ppm: $5.06(\mathrm{~s}, 2 \mathrm{H}), 5.21(\mathrm{~s}, 4 \mathrm{H}), 6.78-6.82(\mathrm{~d}, J=8.0 \mathrm{~Hz}, 2 \mathrm{H}), 6.94-6.98$ $(\mathrm{d}, J=8.0 \mathrm{~Hz}, 2 \mathrm{H}), 7.05-7.15(\mathrm{~m}, 4 \mathrm{H}), 7.36-7.42(\mathrm{~m}, 5 \mathrm{H})$.

\subsection{General Procedure K-Buchwald-Hartwig Reaction via Halides}

A mixture of 1.0 eq. of aryl halide, 1.0 eq. of amine, 3.0 eq. of $\mathrm{Cs}_{2} \mathrm{CO}_{3}$ as the base, 0.5 eq. of X-Phos as the ligand and 0.1 eq. of $\mathrm{Pd}(\mathrm{OAc})_{2}$ as the catalyst in dry 1,4-dioxane and absolute tert-butanol (4:1) $(0.05 \mathrm{M})$ was stirred at reflux under atmosphere of argon. After controlling through TLC and HPLC, the mixture was allowed to cool to room temperature. It was diluted with water and subsequently extracted with ethyl acetate. The extracts were combined, washed with brine and afterwards dried over $\mathrm{Na}_{2} \mathrm{SO}_{4}$. The solvent was removed under vacuum, and the residue was purified by column chromatography, affording the desired product. Adapted from Martz et al. [31].

N-phenyl-6,7,8,9-tetrahydrospiro[benzo[7]annulene-5,3'-oxetan]-2-amine (16a): Brown solid. 86\% yield. HPLC: $9.015 \mathrm{~min}$ (96\%). ESI-MS: Calculated: 279.1 for $\mathrm{C}_{19} \mathrm{H}_{21} \mathrm{NO}$. Found: $278.0[\mathrm{M}-\mathrm{H}]^{-} .{ }^{1} \mathrm{H}-\mathrm{NMR}$ $\left(400 \mathrm{MHz}, \mathrm{CDCl}_{3}\right) \delta$ in ppm: $1.59\left(\mathrm{~m}, 2 \mathrm{H}, \mathrm{CH}_{2}\right), 2.01\left(\mathrm{~m}, 2 \mathrm{H}, \mathrm{CH}_{2}\right), 2.18\left(\mathrm{t}, 2 \mathrm{H}, J=8.0 \mathrm{~Hz}, \mathrm{CH}_{2}\right)$, 
$2.42\left(\mathrm{t}, 2 \mathrm{H}, J=8.0 \mathrm{~Hz}, \mathrm{CH}_{2}\right), 4.73(\mathrm{~d}, 2 \mathrm{H}), 5.04(\mathrm{~d}, 2 \mathrm{H}), 5.78(\mathrm{br}, 1 \mathrm{H}), 6.82(\mathrm{~s}, 1 \mathrm{H}), 6.91-7.00(\mathrm{~m}, 3 \mathrm{H})$, $7.08(\mathrm{~d}, 2 \mathrm{H}, J=8.0 \mathrm{~Hz}), 7.27(\mathrm{t}, 2 \mathrm{H}, J=8.0 \mathrm{~Hz}) ;{ }^{13} \mathrm{C}-\mathrm{NMR}\left(100 \mathrm{MHz}, \mathrm{CDCl}_{3}\right) \delta$ in ppm: 26.5, 27.3, 35.5, $37.1,47.7,80.7,115.1,117.9,119.4,121.0,126.2,129.5,137.1,141.8,143.4$.

N-(2,4-difluorophenyl)-6,7,8,9-tetrahydrospiro[benzo[7]annulene-5,3'-oxetan]-2-amine (16b): Brown solid. 73\% yield. HPLC: $8.542 \mathrm{~min}$ (98\%). ESI-MS: Calculated: 315.1 for $\mathrm{C}_{19} \mathrm{H}_{19} \mathrm{~F}_{2} \mathrm{NO}$. Found: $314.2[\mathrm{M}-\mathrm{H}]^{-}$. ${ }^{1} \mathrm{H}-\mathrm{NMR}\left(400 \mathrm{MHz}, \mathrm{CDCl}_{3}\right) \delta$ in ppm: $1.49(\mathrm{~m}, 2 \mathrm{H}), 1.91(\mathrm{~m}, 2 \mathrm{H}), 2.08(\mathrm{t}, 2 \mathrm{H}), 2.31(\mathrm{t}, 2 \mathrm{H}), 4.63-4.64$ $(\mathrm{d}, 2 \mathrm{H}, J=4.0 \mathrm{~Hz}), 4.93-4.94(\mathrm{~d}, 2 \mathrm{H}, J=4.0 \mathrm{~Hz}), 5.46(\mathrm{br}, 1 \mathrm{H}), 6.66(\mathrm{~s}, 1 \mathrm{H}), 6.70-6.82(\mathrm{~m}, 3 \mathrm{H}), 6.89(\mathrm{~d}, 1 \mathrm{H}$, $J=8.0 \mathrm{~Hz}), 7.18(\mathrm{~s}, 1 \mathrm{H}) ;{ }^{13} \mathrm{C}-\mathrm{NMR}\left(100 \mathrm{MHz}, \mathrm{CDCl}_{3}\right) \delta$ in ppm: $26.5,27.3,37.1,47.7,80.7,104.1$ $\left(\mathrm{dd}, J_{1}=23.6 \mathrm{~Hz}, J_{2}=23.7 \mathrm{~Hz}\right), 110.9\left(\mathrm{dd}, J_{1}=3.64 \mathrm{~Hz}, J_{2}=3.71 \mathrm{~Hz}\right), 114.9,119.3,119.5\left(\mathrm{dd}, J_{1}=2.28 \mathrm{~Hz}\right.$, $\left.J_{2}=3.17 \mathrm{~Hz}\right), 126.4,127.9\left(\mathrm{dd}, J_{1}=2.35 \mathrm{~Hz}, J_{2}=2.36 \mathrm{~Hz}\right), 137.6,141.4,143.6$.

$\mathrm{N}$-(2-(trifluoromethyl)phenyl)-6,7,8,9-tetrahydrospiro[benzo[7]annulene-5,3'-oxetan]-2-amine(16c): Yellow solid. 77\% yield. HPLC: $10.008 \mathrm{~min}$ (96\%). ESI-MS: Calculated: 347.1 for $\mathrm{C}_{20} \mathrm{H}_{20} \mathrm{~F}_{3} \mathrm{NO}$. Found: $346.1[\mathrm{M}-\mathrm{H}]^{-}$. ${ }^{1} \mathrm{H}-\mathrm{NMR}\left(400 \mathrm{MHz}, \mathrm{CDCl}_{3}\right) \delta$ in ppm: $1.58(\mathrm{~m}, 2 \mathrm{H}), 1.99(\mathrm{~m}, 2 \mathrm{H}), 2.17(\mathrm{t}, 2 \mathrm{H}), 2.42(\mathrm{t}, 2 \mathrm{H}), 4.73(\mathrm{~d}, 2 \mathrm{H})$, $5.02(\mathrm{~d}, 2 \mathrm{H}), 6.02(\mathrm{br}, 1 \mathrm{H}), 6.84(\mathrm{~s}, 1 \mathrm{H}), 6.90-6.96(\mathrm{~m}, 2 \mathrm{H}), 7.01(\mathrm{~d}, 1 \mathrm{H}, J=8.0 \mathrm{~Hz}), 7.32-7.39(\mathrm{~m}, 2 \mathrm{H})$, $7.54(\mathrm{~d}, 1 \mathrm{H}, J=8.0 \mathrm{~Hz}) ;{ }^{13} \mathrm{C}-\mathrm{NMR}\left(100 \mathrm{MHz}, \mathrm{CDCl}_{3}\right) \delta$ in ppm: 26.5, 27.2, 35.4, 36.9, 47.8, 80.7, 117.2, 117.5, $117.7(\mathrm{~d}, J=10.6 \mathrm{~Hz}), 119.6,122.0,123.6,126.4,127.0\left(\mathrm{dd}, J_{1}=5.5 \mathrm{~Hz}, J_{2}=5.4 \mathrm{~Hz}\right), 132.8,139.0,140.1$, $142.5,143.7$.

N-(4-methoxyphenyl)-6,7,8,9-tetrahydrospiro[benzo[7]annulene-5,3'-oxetan]-2-amine (16d): Yellow solid. 86\% yield. HPLC: 7.976 min (98\%). ESI-MS: Calculated: 309.1 for $\mathrm{C}_{20} \mathrm{H}_{23} \mathrm{NO}_{2}$. Found: $308.0[\mathrm{M}-\mathrm{H}]^{-}$. ${ }^{1} \mathrm{H}-\mathrm{NMR}\left(200 \mathrm{MHz}, \mathrm{CDCl}_{3}\right) \delta$ in ppm: $1.58(\mathrm{~m}, 2 \mathrm{H}), 1.98(\mathrm{~m}, 2 \mathrm{H}), 2.17(\mathrm{t}, 2 \mathrm{H}), 2.43(\mathrm{t}, 2 \mathrm{H}), 3.80(\mathrm{~s}, 3 \mathrm{H})$, $4.67(\mathrm{~d}, 2 \mathrm{H}, J=6.0 \mathrm{~Hz}), 4.99(\mathrm{~d}, 2 \mathrm{H}, J=6.0 \mathrm{~Hz}), 5.45(\mathrm{br}, 1 \mathrm{H}), 6.63-6.74(\mathrm{~m}, 3 \mathrm{H}), 6.84-6.93(\mathrm{~m}, 3 \mathrm{H})$, $7.04(\mathrm{t}, 2 \mathrm{H}) ;{ }^{13} \mathrm{C}-\mathrm{NMR}\left(100 \mathrm{MHz}, \mathrm{CDCl}_{3}\right) \delta$ in ppm: 26.6, 27.3, 35.6, 37.2, 47.9, 55.7, 112.8, 114.8, 117.3, $122.2,126.2,135.6,136.0,143.3,143.9,155.4$.

N-phenyl-3,4-dihydro-2H-spiro[naphthalene-1,3'-oxetan]-6-amine (17a): Brown solid. 92\% yield. HPLC: $7.967 \mathrm{~min}$ (97\%). ESI-MS: Calculated: 265.1 for $\mathrm{C}_{18} \mathrm{H}_{19} \mathrm{NO}$. Found: $264.0[\mathrm{M}-\mathrm{H}]^{-} .{ }^{1} \mathrm{H}-\mathrm{NMR}(200 \mathrm{MHz}$, $\left.\mathrm{CDCl}_{3}\right) \delta$ in ppm: $1.75-1.84(\mathrm{~m}, 2 \mathrm{H}), 2.24(\mathrm{t}, 2 \mathrm{H}, J=6.0 \mathrm{~Hz}), 2.75(\mathrm{t}, 2 \mathrm{H}, J=6.0 \mathrm{~Hz}), 4.66(\mathrm{~d}, 2 \mathrm{H}$, $J=6.0 \mathrm{~Hz}), 4.87(\mathrm{~d}, 2 \mathrm{H}, J=6.0 \mathrm{~Hz}), 6.84(\mathrm{~s}, 1 \mathrm{H}), 6.94-7.10(\mathrm{~m}, 4 \mathrm{H}), 7.33(\mathrm{t}, 2 \mathrm{H}), 7.83(\mathrm{~d}, 2 \mathrm{H}, J=8.0 \mathrm{~Hz})$; ${ }^{13} \mathrm{C}-\mathrm{NMR}\left(50 \mathrm{MHz}, \mathrm{CDCl}_{3}\right.$ ) $\delta$ in ppm: 20.3, 30.4, 35.9, 42.1, 85.8, 116.8, 117.4, 117.9, 121.1, 127.7, 129.5, 132.1, 138.1, 141.7, 143.2.

N-(2,4-difluorophenyl)-3,4-dihydro-2H-spiro[naphthalene-1,3'-oxetan]-6-amine(17b): Brown solid. 51\% yield. HPLC: 8.586 min (98\%). ESI-MS: Calculated: 301.1 for $\mathrm{C}_{18} \mathrm{H}_{17} \mathrm{~F}_{2} \mathrm{NO}$. Found: 299.9 [M - H] ${ }^{-} .{ }^{1} \mathrm{H}-\mathrm{NMR}$ $\left(200 \mathrm{MHz}, \mathrm{CDCl}_{3}\right) \delta$ in ppm: 1.70-1.79 (m, 2H), $2.19(\mathrm{t}, 2 \mathrm{H}, J=6.0 \mathrm{~Hz}), 2.70(\mathrm{t}, 2 \mathrm{H}, J=6.0 \mathrm{~Hz}), 4.61(\mathrm{~d}, 2 \mathrm{H}$, $J=6.0 \mathrm{~Hz}), 4.80(\mathrm{~d}, 2 \mathrm{H}, J=6.0 \mathrm{~Hz}), 6.70-6.99(\mathrm{~m}, 4 \mathrm{H}), 7.19-7.31(\mathrm{~m}, 1 \mathrm{H}), 7.79(\mathrm{~d}, 2 \mathrm{H}, J=10 \mathrm{~Hz}) ;{ }^{13} \mathrm{C}-\mathrm{NMR}$ (50 MHz, $\mathrm{CDCl}_{3}$ ) $\delta$ in ppm: 20.3, 30.4, 35.8, 42.1, 85.8, $103.9\left(\mathrm{dd}, J_{1}=23.5 \mathrm{~Hz}, J_{2}=23.5 \mathrm{~Hz}\right), 110.8(\mathrm{dd}$, $\left.J_{1}=3.76 \mathrm{~Hz}, J_{2}=3.79 \mathrm{~Hz}\right), 116.5,117.3,119.6\left(\mathrm{dd}, J_{1}=3.22 \mathrm{~Hz}, J_{2}=3.30 \mathrm{~Hz}\right), 127.9,132.7,138.3,141.3$, $151.0(\mathrm{~d}, J=11.8 \mathrm{~Hz}), 154.5(\mathrm{~d}, J=11.1 \mathrm{~Hz}), 155.9(\mathrm{~d}, J=11.8 \mathrm{~Hz}), 159.3(\mathrm{~d}, J=11.3 \mathrm{~Hz})$.

$\mathrm{N}$-(2-(trifluoromethyl)phenyl)-3,4-dihydro-2H-spiro[naphthalene-1,3'-oxetan]-6-amine (17c): White solid. 82\% yield. HPLC: $9.943 \mathrm{~min}$ (98\%). ESI-MS: Calculated: 333.1 for $\mathrm{C}_{19} \mathrm{H}_{18} \mathrm{~F}_{3} \mathrm{NO}$. Found: $332.2[\mathrm{M}-\mathrm{H}]^{-}$. ${ }^{1} \mathrm{H}-\mathrm{NMR}\left(200 \mathrm{MHz}, \mathrm{CDCl}_{3}\right) \delta$ in ppm: 1.71-1.74 (m, 2H), $2.20(\mathrm{t}, 2 \mathrm{H}, J=6.0 \mathrm{~Hz}), 2.72(\mathrm{t}, 2 \mathrm{H}, J=6.0 \mathrm{~Hz})$, $4.63(\mathrm{~d}, 2 \mathrm{H}, J=6.0 \mathrm{~Hz}), 4.82(\mathrm{~d}, 2 \mathrm{H}, J=6.0 \mathrm{~Hz}), 6.03(\mathrm{br}, 1 \mathrm{H}), 6.83(\mathrm{~s}, 1 \mathrm{H}), 6.94(\mathrm{t}, 1 \mathrm{H}, J=8.0 \mathrm{~Hz}), 7.06(\mathrm{~d}, 1 \mathrm{H}$, $J=8.0 \mathrm{~Hz}), 7.32-7.43(\mathrm{~m}, 2 \mathrm{H}), 7.54(\mathrm{~d}, 1 \mathrm{H}, J=8.0 \mathrm{~Hz}), 7.84(\mathrm{~d}, 1 \mathrm{H}, J=8.0 \mathrm{~Hz}) ;{ }^{13} \mathrm{C}-\mathrm{NMR}(50 \mathrm{MHz}$, $\left.\mathrm{CDCl}_{3}\right) \delta$ in ppm: $20.3,30.3,35.8,42.2,85.8,117.3,117.9,118.0,118.9,119.8,120.1,126.9\left(\mathrm{dd}, J_{1}=5.5 \mathrm{~Hz}\right.$, $\left.J_{2}=5.5 \mathrm{~Hz}\right), 127.9,132.7,134.1,138.3,140.1,142.2$.

$\mathrm{N}$-(2-methoxyphenyl)-3,4-dihydro-2H-spiro[naphthalene-1,3'-oxetan]-6-amine (17d): Yellow solid. 82\% yield. HPLC: $9.221 \mathrm{~min}$ (95\%). ESI-MS: Calculated: 295.1 for $\mathrm{C}_{19} \mathrm{H}_{21} \mathrm{NO}_{2}$. Found: $294.4[\mathrm{M}-\mathrm{H}]^{-} .{ }^{1} \mathrm{H}-\mathrm{NMR}$ $\left(200 \mathrm{MHz}, \mathrm{CDCl}_{3}\right) \delta$ in ppm: $1.72-1.83(\mathrm{~m}, 2 \mathrm{H}), 2.24(\mathrm{t}, 2 \mathrm{H}, J=6.0 \mathrm{~Hz}), 2.76(\mathrm{t}, 2 \mathrm{H}, J=6.0 \mathrm{~Hz}), 3.93(\mathrm{~s}$, $3 \mathrm{H}), 4.66(\mathrm{~d}, 2 \mathrm{H}, J=6.0 \mathrm{~Hz}), 4.87(\mathrm{~d}, 2 \mathrm{H}, J=6.0 \mathrm{~Hz}), 6.92(\mathrm{~m}, 4 \mathrm{H}), 7.13(\mathrm{~d}, 1 \mathrm{H}), 7.32(\mathrm{~m}, 1 \mathrm{H}), 7.84(\mathrm{~d}, 1 \mathrm{H}$, 
$J=8.0 \mathrm{~Hz}) ;{ }^{13} \mathrm{C}-\mathrm{NMR}\left(50 \mathrm{MHz}, \mathrm{CDCl}_{3}\right) \delta$ in ppm: 20.4, 30.4, 35.9, 42.1, 55.7, 85.8, 110.7, 114.9, 117.5, $118.2,120.0,120.9,127.7,132.3,133.0,138.0,141.3,148.4$.

N-phenyl-2,3-dihydrospiro[indene-1,3'-oxetan]-5-amine (18a): Brown solid. 71\% yield. HPLC: $8.231 \mathrm{~min}$ (95\%). ESI-MS: Calculated: 251.1 for $\mathrm{C}_{17} \mathrm{H}_{17} \mathrm{NO}$. Found: $250.1[\mathrm{M}-\mathrm{H}]^{-} .{ }^{1} \mathrm{H}-\mathrm{NMR}\left(200 \mathrm{MHz}, \mathrm{CDCl}_{3}\right)$ $\delta$ in ppm: $2.52(\mathrm{t}, 2 \mathrm{H}, J=8.0 \mathrm{~Hz}), 2.89(\mathrm{~d}, 2 \mathrm{H}, J=8.0 \mathrm{~Hz}), 4.83-4.92(\mathrm{~m}, 4 \mathrm{H}), 5.82(\mathrm{br}, 1 \mathrm{H}), 6.94-7.12(\mathrm{~m}$, $5 \mathrm{H}), 7.28-7.36(\mathrm{~m}, 2 \mathrm{H}), 7.57(\mathrm{~d}, 2 \mathrm{H}, J=8.0 \mathrm{~Hz}) ;{ }^{13} \mathrm{C}-\mathrm{NMR}\left(50 \mathrm{MHz}, \mathrm{CDCl}_{3}\right) \delta$ in ppm: 30.6, 38.4, 50.9, $84.6,113.8,117.4,177.9,121.1,123.6,129.5,138.8,143.0,143.5,144.9$.

N-(2,4-difluorophenyl)-2,3-dihydrospiro[indene-1,3'-oxetan]-5-amine (18b): Brown solid. 76\% yield. HPLC: $8.670 \mathrm{~min}(100 \%)$. ESI-MS: Calculated: 287.1 for $\mathrm{C}_{17} \mathrm{H}_{15} \mathrm{~F}_{2} \mathrm{NO}$. Found: $286.1[\mathrm{M}-\mathrm{H}]^{-}$. ${ }^{1} \mathrm{H}-\mathrm{NMR}$ $\left(200 \mathrm{MHz} \mathrm{CDCl}_{3}\right) \delta$ in ppm: $2.47(\mathrm{t}, 2 \mathrm{H}, J=6.0 \mathrm{~Hz}), 2.89(\mathrm{~d}, 2 \mathrm{H}, J=6.0 \mathrm{~Hz}), 4.79-4.87(\mathrm{~m}, 4 \mathrm{H}), 6.76-6.98$ $(\mathrm{m}, 4 \mathrm{H}), 7.17-7.29(\mathrm{~m}, 1 \mathrm{H}), 7.53(\mathrm{~d}, 2 \mathrm{H}, J=8.0 \mathrm{~Hz}) ;{ }^{13} \mathrm{C}-\mathrm{NMR}\left(100 \mathrm{MHz}, \mathrm{CDCl}_{3}\right) \delta$ in ppm: 30.6, $38.3,50.9,84.6,103.9,104.4(J=2.87 \mathrm{~Hz}), 110.8\left(J_{1}=3.83, J_{2}=3.97 \mathrm{~Hz}\right), 113.6,117.3,119.6\left(J_{1}=2.86\right.$, $\left.J_{2}=3.34 \mathrm{~Hz}\right), 123.7,139.3,142.7,145.1$.

N-(2-(trifluoromethyl)phenyl)-2,3-dihydrospiro[indene-1,3'-oxetan]-5-amine (18c): White solid. 95\% yield. HPLC: $9.588 \mathrm{~min}$ (100\%). ESI-MS: Calculated: 319.1 for $\mathrm{C}_{18} \mathrm{H}_{16} \mathrm{~F}_{3} \mathrm{NO}$. Found: $318.1[\mathrm{M}-\mathrm{H}]^{-} .{ }^{1} \mathrm{H}-\mathrm{NMR}$ $\left(200 \mathrm{MHz}, \mathrm{CDCl}_{3}\right) \delta$ in ppm: $2.49(\mathrm{t}, 2 \mathrm{H}, J=8.0 \mathrm{~Hz}), 2.86(\mathrm{~d}, 2 \mathrm{H}, J=8.0 \mathrm{~Hz}), 4.80-4.88(\mathrm{~m}, 4 \mathrm{H}), 6.06(\mathrm{br}$, $1 \mathrm{H}), 6.90-6.97(\mathrm{~m}, 2 \mathrm{H}), 7.04(\mathrm{~d}, 2 \mathrm{H}, J=8.0 \mathrm{~Hz}), 7.29-7.41(\mathrm{~m}, 2 \mathrm{H}), 7.58(\mathrm{t}, 2 \mathrm{H}, J=8.0 \mathrm{~Hz}) ;{ }^{13} \mathrm{C}-\mathrm{NMR}$ $\left(50 \mathrm{MHz}, \mathrm{CDCl}_{3}\right) \delta$ in ppm: 30.6, 38.2, 50.9, 84.5, 116.5, 117.9, 119.8, 123.7, 127.1, 132.8, 140.7, 141.4, $142.5,145.1$.

N-(2-methoxyphenyl)-2,3-dihydrospiro[indene-1,3'-oxetan]-5-amine (18d): Yellow solid. 80\% yield. HPLC: $8.718 \mathrm{~min}(98 \%)$. ESI-MS: Calculated: 281.1 for $\mathrm{C}_{18} \mathrm{H}_{19} \mathrm{NO}_{2}$. Found: $280.1[\mathrm{M}-\mathrm{H}]^{-}$. ${ }^{1} \mathrm{H}-\mathrm{NMR}$ $\left(200 \mathrm{MHz}, \mathrm{CDCl}_{3}\right) \delta$ in ppm: $2.48(\mathrm{t}, 2 \mathrm{H}, J=8.0 \mathrm{~Hz}), 2.86(\mathrm{~d}, 2 \mathrm{H}, J=8.0 \mathrm{~Hz}), 3.89(\mathrm{~s}, 3 \mathrm{H}), 4.79-4.89(\mathrm{~m}$, $4 \mathrm{H}), 6.15(\mathrm{br}, 1 \mathrm{H}), 6.85-6.91(\mathrm{~m}, 3 \mathrm{H}), 7.02(\mathrm{~s}, 1 \mathrm{H}), 7.07(\mathrm{~d}, 1 \mathrm{H}), 7.28(\mathrm{~m}, 1 \mathrm{H}), 7.54(\mathrm{~d}, 2 \mathrm{H}, J=8.0 \mathrm{~Hz})$; ${ }^{13} \mathrm{C}-\mathrm{NMR}\left(50 \mathrm{MHz}, \mathrm{CDCl}_{3}\right.$ ) $\delta$ in ppm: 30.6, 38.4, 50.9, 55.7, 84.6, 110.6, 114.5, 114.8, 118.1, 119.9, 120.9, $123.5,133.3,138.9,142.6,144.8,148.3$.

4-(3-methyloxetan-3-yl)-N-phenylaniline (19a): Brown solid. 83\% yield. HPLC: $7.967 \mathrm{~min}$ (96\%). ESI-MS: Calculated: 239.1 for $\mathrm{C}_{16} \mathrm{H}_{17} \mathrm{NO}$. Found: $238.0[\mathrm{M}-\mathrm{H}]^{-} .{ }^{1} \mathrm{H}-\mathrm{NMR}\left(400 \mathrm{MHz}, \mathrm{CDCl}_{3}\right) \delta$ in ppm: 1.75 (s, $\left.3 \mathrm{H}, \mathrm{CH}_{3}\right), 4.65-4.66\left(\mathrm{~d}, 2 \mathrm{H}, J=4.0 \mathrm{~Hz}, \mathrm{CH}_{2}\right), 4.98-4.99\left(\mathrm{~d}, 2 \mathrm{H}, J=4.0 \mathrm{~Hz}, \mathrm{CH}_{2}\right), 5.76(\mathrm{br}, 1 \mathrm{H}), 6.94-6.97$ $(\mathrm{t}, 1 \mathrm{H}, J=8.0 \mathrm{~Hz}), 7.08-7.11(\mathrm{~m}, 4 \mathrm{H}), 7.16-7.18(\mathrm{~d}, 2 \mathrm{H}, J=8.0 \mathrm{~Hz}), 7.28-7.36(\mathrm{t}, 2 \mathrm{H}, J=8.0 \mathrm{~Hz}) ;{ }^{13} \mathrm{C}-\mathrm{NMR}$ $\left(100 \mathrm{MHz}, \mathrm{CDCl}_{3}\right) \delta$ in ppm: 27.7, 43.0, 84.2, 117.8, 118.2, 121.1, 126.2, 129.5, 139.1, 141.6, 143.4.

2,4-difluoro-N-(4-(3-methyloxetan-3-yl)phenyl)aniline (19b): Brown solid. 71\% yield. HPLC: 7.689 min (100\%). ESI-MS: Calculated: 275.1 for $\mathrm{C}_{16} \mathrm{H}_{15} \mathrm{~F}_{2} \mathrm{NO}$. Found: $274.0[\mathrm{M}-\mathrm{H}]^{-} .{ }^{1} \mathrm{H}-\mathrm{NMR}(200 \mathrm{MHz}$, $\left.\mathrm{CDCl}_{3}\right) \delta$ in ppm: $1.73(\mathrm{~s}, 3 \mathrm{H}), 4.62(\mathrm{~d}, 2 \mathrm{H}, J=6.0 \mathrm{~Hz}), 4.94(\mathrm{~d}, 2 \mathrm{H}, J=6.0 \mathrm{~Hz}), 6.75-6.95(\mathrm{~m}, 2 \mathrm{H})$, $6.99(\mathrm{~d}, 2 \mathrm{H}, J=10 \mathrm{~Hz}), 7.14(\mathrm{~d}, 2 \mathrm{H}, J=8.0 \mathrm{~Hz}), 7.23-7.28(\mathrm{~d}, 1 \mathrm{H}) ;{ }^{13} \mathrm{C}-\mathrm{NMR}\left(50 \mathrm{MHz}, \mathrm{CDCl}_{3}\right) \delta$ in ppm: $27.7,42.9,84.1,103.9\left(\mathrm{dd}, J_{1}=23.5 \mathrm{~Hz}, J_{2}=23.5 \mathrm{~Hz}\right), 110.8\left(\mathrm{dd}, J_{1}=3.8 \mathrm{~Hz}, J_{2}=3.8 \mathrm{~Hz}\right), 117.9,119.3(\mathrm{dd}$, $\left.J_{1}=3.4 \mathrm{~Hz}, J_{2}=3.3 \mathrm{~Hz}\right), 126.3,127.8\left(\mathrm{dd}, J_{1}=3.4 \mathrm{~Hz}, J_{2}=3.1 \mathrm{~Hz}\right), 139.6,141.2,150.9(\mathrm{~d}, J=11.9 \mathrm{~Hz})$, $154.5(\mathrm{~d}, J=11.1 \mathrm{~Hz}), 155.8(\mathrm{~d}, J=11.7 \mathrm{~Hz}), 159.3(\mathrm{~d}, J=11.1 \mathrm{~Hz})$.

$\mathrm{N}$-(4-(3-methyloxetan-3-yl)phenyl)-2-(trifluoromethyl)aniline (19c): White solid. 88\% yield. HPLC: 9.306 min (100\%). ESI-MS: Calculated: 307.1 for $\mathrm{C}_{17} \mathrm{H}_{16} \mathrm{~F}_{3} \mathrm{NO}$. Found: $306.0[\mathrm{M}-\mathrm{H}]^{-}$. ${ }^{1} \mathrm{H}-\mathrm{NMR}$ $\left(400 \mathrm{MHz}, \mathrm{CDCl}_{3}\right) \delta$ in ppm: $1.78\left(\mathrm{~s}, 3 \mathrm{H}, \mathrm{CH}_{3}\right), 4.67-4.70\left(\mathrm{~d}, 2 \mathrm{H}, J=6.0 \mathrm{~Hz}, \mathrm{CH}_{2}\right), 4.99-5.02(\mathrm{~d}, 2 \mathrm{H}$, $\left.J=6.0 \mathrm{~Hz}, \mathrm{CH}_{2}\right), 6.10(\mathrm{br}, 1 \mathrm{H}), 6.94-7.02(\mathrm{t}, 1 \mathrm{H}, J=8.0 \mathrm{~Hz}), 7.13-7.25(\mathrm{q}, 4 \mathrm{H}), 7.30-7.41(\mathrm{~m}, 2 \mathrm{H}), 7.59-7.63$ $(\mathrm{d}, 2 \mathrm{H}, J=8.0 \mathrm{~Hz}) ;{ }^{13} \mathrm{C}-\mathrm{NMR}\left(100 \mathrm{MHz}, \mathrm{CDCl}_{3}\right) \delta$ in ppm: 27.7, 43.1, 84.0, 114.3, 117.7, 119.8, 120.7, $126.4,127.1,132.8,140.0,140.7,141.1,142.4$.

2-methoxy-N-(4-(3-methyloxetan-3-yl)phenyl)aniline (19d): Yellow solid. 81\% yield. HPLC: 8.251 min (98\%). EI-MS: Calculated: 269.1 for $\mathrm{C}_{17} \mathrm{H}_{19} \mathrm{NO}_{2}$. Found: 269.1. ${ }^{1} \mathrm{H}-\mathrm{NMR}\left(400 \mathrm{MHz}, \mathrm{CDCl}_{3}\right) \delta$ in ppm: $1.73\left(\mathrm{~s}, 3 \mathrm{H}, \mathrm{CH}_{3}\right), 3.90\left(\mathrm{~s}, 3 \mathrm{H}, \mathrm{OCH}_{3}\right), 4.62-4.64\left(\mathrm{~d}, 2 \mathrm{H}, J=8.0 \mathrm{~Hz}, \mathrm{CH}_{2}\right), 4.96-4.97(\mathrm{~d}, 2 \mathrm{H}, J=4.0 \mathrm{~Hz}$, 
$\left.\mathrm{CH}_{2}\right), 6.85-6.90(\mathrm{~m}, 3 \mathrm{H}), 7.15(\mathrm{~s}, 4 \mathrm{H}), 7.27-7.29(\mathrm{~d}, 1 \mathrm{H}) ;{ }^{13} \mathrm{C}-\mathrm{NMR}\left(100 \mathrm{MHz}, \mathrm{CDCl}_{3}\right) \delta$ in ppm: 27.7, 43.0, 55.7, 84.2, 110.7, 114.7, 118.9, 120.0, 120.9, 126.1, 133.2, 139.2, 141.2, 148.4.

\subsection{General Procedure L-Buchwald-Hartwig Reaction via Triflates—Benzyl Ether Deprotection}

A mixture of aryl triflate, amine, $\mathrm{Cs}_{2} \mathrm{CO}_{3}$ as the base, BINAP as the ligand and $\mathrm{Pd}(\mathrm{OAc})_{2}$ as the catalyst in dry 1,4-dioxane and absolute tert-butanol (4:1) (0.03 M) was stirred at $110{ }^{\circ} \mathrm{C}$ under an atmosphere of argon. After controlling through TLC and HPLC, the mixture was allowed to cool to room temperature. It was diluted with water and subsequently extracted with ethyl acetate. The extracts were combined, washed with brine and afterwards dried over $\mathrm{Na}_{2} \mathrm{SO}_{4}$. The solvent was removed under vacuum, and the residue was purified by column chromatography, affording the product. Adapted from Åhman and Buchwald [33].

Then the benzyl ether deprotection was performed as follows: 0.6 eq. of palladium on carbon $(10 \% w / w)$ was added to a solution of oxetane in ethanol/acetonitrile. The reaction mixture was stirred under an atmosphere of hydrogen at $25^{\circ} \mathrm{C}$ until HPLC analysis indicated the end of reaction. The reaction mixture was filtered through celite, washed through with ethanol and then concentrated in vacuum to afford the final oxetane. Adapted from Croft et al. [28].

4-(3-(4-(phenylamino)phenyl)oxetan-3-yl)phenol (20a): White solid. 85\% yield. HPLC: $7.618 \mathrm{~min}(96 \%)$. ESI-MS: Calculated: 317.1 for $\mathrm{C}_{21} \mathrm{H}_{19} \mathrm{NO}_{2}$. Found: $316.2[\mathrm{M}-\mathrm{H}]^{-} .{ }^{1} \mathrm{H}-\mathrm{NMR}(400 \mathrm{MHz}, d$-acetone) $\delta$ in ppm: $5.13(\mathrm{~s}, 4 \mathrm{H}), 6.82-6.85(\mathrm{t}, 3 \mathrm{H}), 7.10-7.17(\mathrm{~m}, 8 \mathrm{H}), 7.20-7.24(\mathrm{t}, 2 \mathrm{H}), 7.41(\mathrm{br}, 1 \mathrm{H}) ;{ }^{13} \mathrm{C}-\mathrm{NMR}$ (100 MHz, $d$-acetone) $\delta$ in ppm: 51.3, 84.9, 116.1, 117.9, 118.1, 120.9, 128.0, 129.9, 138.5, 139.5, 142.9, 144.7, 156.7 .

4-(3-(4-((2,4-difluorophenyl)amino)phenyl)oxetan-3-yl)phenol (20b): Brown solid. 66\% yield. HPLC: $7.930 \mathrm{~min}$ (98\%). ESI-MS: Calculated: 353.1 for $\mathrm{C}_{21} \mathrm{H}_{17} \mathrm{~F}_{2} \mathrm{NO}_{2}$. Found: $352.0[\mathrm{M}-\mathrm{H}]^{-}$. ${ }^{1} \mathrm{H}-\mathrm{NMR}$ (400 MHz, $d$-acetone) $\delta$ in ppm: $5.12(\mathrm{~s}, 4 \mathrm{H}), 6.81-6.83(\mathrm{~d}, 2 \mathrm{H}, J=8.0 \mathrm{~Hz}), 6.90-6.95(\mathrm{t}, 1 \mathrm{H}), 7.0-7.02$ $(\mathrm{d}, 2 \mathrm{H}, J=8.0 \mathrm{~Hz}), 7.11-7.13(\mathrm{~d}, 2 \mathrm{H}, J=8.0 \mathrm{~Hz}), 7.15-7.17(\mathrm{~d}, 2 \mathrm{H}, J=8.0 \mathrm{~Hz}), 7.32-7.38(\mathrm{~m}, 1 \mathrm{H})$, 8.29 (br, $1 \mathrm{H}) ;{ }^{13} \mathrm{C}-\mathrm{NMR}(100 \mathrm{MHz}, d$-acetone) $\delta$ in ppm: 51.6, 85.0, 104.9, $105.1(\mathrm{~d}, J=3.0 \mathrm{~Hz}), 105.4$, $111.9(\mathrm{~d}, J=4.0 \mathrm{~Hz}), 112.1(\mathrm{~d}, J=4.0 \mathrm{~Hz}), 116.3,117.9,122.1(\mathrm{~d}, J=3.0 \mathrm{~Hz}), 122.2(\mathrm{~d}, J=3.0 \mathrm{~Hz}), 128.3$, $128.5,138.7,140.0,143.3,156.9$.

4-(3-(4-((4-(trifluoromethyl)phenyl)amino)phenyl)oxetan-3-yl)phenol (20c): White solid. 71\% yield. HPLC: 7.967 min (96\%). ESI-MS: Calculated: 385.1 for $\mathrm{C}_{22} \mathrm{H}_{18} \mathrm{~F}_{3} \mathrm{NO}_{2}$. Found: $383.9[\mathrm{M}-\mathrm{H}]^{-}$. ${ }^{1} \mathrm{H}-\mathrm{NMR}$ (200 MHz, $d$-acetone) $\delta$ in ppm: $5.15(\mathrm{~s}, 4 \mathrm{H}), 6.82-6.86(\mathrm{~d}, 2 \mathrm{H}, J=8.0 \mathrm{~Hz}), 7.11-7.29(\mathrm{~m}, 8 \mathrm{H}), 7.49-7.53$ $(\mathrm{d}, 2 \mathrm{H}, J=8.0 \mathrm{~Hz}), 7.93(\mathrm{br}, 1 \mathrm{H}), 8.34(\mathrm{br}, 1 \mathrm{H}) ;{ }^{13} \mathrm{C}-\mathrm{NMR}(50 \mathrm{MHz}, d$-acetone) $\delta$ in ppm: 51.5, 84.8, 115.7, $116.1,120.5,121.0,127.3,127.4,128.2,128.4,138.3,140.9,141.8,148.8,156.8$.

4-(3-(4-((4-methoxyphenyl)amino)phenyl)oxetan-3-yl)phenol (20d): Yellow solid. 54\% yield. HPLC: $7.159 \mathrm{~min}(99 \%)$. ESI-MS: Calculated: 347.1 for $\mathrm{C}_{22} \mathrm{H}_{21} \mathrm{NO}_{3}$. Found: $345.9[\mathrm{M}-\mathrm{H}]^{-}$. ${ }^{1} \mathrm{H}-\mathrm{NMR}$ $(400 \mathrm{MHz}, d$-acetone) $\delta$ in ppm: $3.75(\mathrm{~s}, 3 \mathrm{H}), 5.11(\mathrm{~s}, 4 \mathrm{H}), 6.80-6.89(\mathrm{t}, 4 \mathrm{H}), 6.93-6.97(\mathrm{~d}, 2 \mathrm{H}, J=8.0 \mathrm{~Hz})$, 7.07-7.13 (m, 7H); ${ }^{13} \mathrm{C}-\mathrm{NMR}$ (100 MHz, $d$-acetone) $\delta$ in ppm: 27.7, 43.0, 84.2, 117.8, 118.2, 121.1, 126.2, $129.5,139.1,141.6,143.4$.

4-((4-(3-(4-hydroxyphenyl)oxetan-3-yl)phenyl)amino)benzonitrile (20e): Yellow solid. 70\% yield. HPLC: 6.883 min (96\%). ESI-MS: Calculated: 342.1 for $\mathrm{C}_{22} \mathrm{H}_{18} \mathrm{~N}_{2} \mathrm{O}_{2}$. Found: $341.1[\mathrm{M}-\mathrm{H}]^{-}$. ${ }^{1} \mathrm{H}-\mathrm{NMR}$ $(200 \mathrm{MHz}, d$-acetone) $\delta$ in ppm: $5.15(\mathrm{~s}, 4 \mathrm{H}), 6.81-6.86(\mathrm{~d}, 2 \mathrm{H}, J=10 \mathrm{~Hz}), 7.11-7.16(\mathrm{~d}, 2 \mathrm{H}, J=10 \mathrm{~Hz})$, $7.20-7.31(\mathrm{dd}, 4 \mathrm{H}, J=10 \mathrm{~Hz}, J=8.0 \mathrm{~Hz}), 7.52-7.56(\mathrm{~d}, 2 \mathrm{H}, J=8.0 \mathrm{~Hz}), 8.12(\mathrm{br}, 1 \mathrm{H}), 8.32(\mathrm{br}, 1 \mathrm{H})$;

${ }^{13} \mathrm{C}-\mathrm{NMR}(50 \mathrm{MHz}, d$-acetone) $\delta$ in ppm: $51.6,84.8,101.5,115.7,116.2,120.4,121.5,128.4,128.5,134.5$, $138.3,140.1,142.7,149.7,156.9$.

\section{Conclusions}

We successfully synthesized the spiro and the methyl-phenyl oxetane scaffolds in good and reproducible yields. The hydroxyl replacement via oxyphosphonium salts proved to be a winning 
strategy for the synthesis of oxetanes from the aryl-alkyl diols through a cyclization reaction. Additionally, the reaction of phenol with a functionalized oxetan-3-ol was pivotal to obtain the 3,3-diaryloxetanes. Five scaffolds and novel compounds possessing different electronic properties were synthesized using the Buchwald-Hartwig reaction, which worked well for all halides and triflate derivatives.

We succeeded in finding three new hits against the CAMK1G and AAK1 through a screening in a kinase panel using the DSF method. The results indicate that it is possible to explore compounds bearing the oxetane motif in medicinal chemistry, aiming at the discovery of novel kinase inhibitor prototypes. However, some results demonstrated that the oxetane group is probably not interacting in the hinge region, which could be associated to conformational variations or to directional hydrogen bonding differences between $\mathrm{sp}_{2}$ - and $\mathrm{sp}_{3}$-hybridized oxygen atoms.

As a perspective, new experiments could be carried out to determine the $\mathrm{K}_{\mathrm{d}}$ and $\mathrm{IC}_{50}$ of the hit compounds. Furthermore, it is also possible to extensively expand the chemical space of oxetanes using other palladium-catalyzed coupling reactions, such as Sonogashira, Suzuki and Heck.

In addition to these preliminary results, new structural modifications and experiments to measure the $\mathrm{K}_{\mathrm{d}}$ and $\mathrm{IC}_{50}$ will be carried out for a better understanding of the structure-activity relationship.

Author Contributions: Conceptualization, F.R.d.S.A. and S.L.; methodology, F.R.d.S.A. and R.M.C.; writing-original draft preparation, F.R.d.S.A. and S.L. All authors have read and agreed to the published version of the manuscript.

Funding: This research was funded by the Brazilian agencies FAPESP (Fundação de Amparo à Pesquisa do Estado de São Paulo) (2013/50724-5 and 2014/50897-0) and CNPq (Conselho Nacional de Desenvolvimento Científico e Tecnológico) (465651/2014-3) and the University of Tübingen.

Acknowledgments: The present work was possible with financial support of the Brazilian National Council for Scientific and Technological Development (CNPq) and of the University of Tübingen. The authors also thank Gerd Helms for some NMR experiments and Paulo Godoi for the Kinase experiments at the Structural Genomics Consortium-SGC (Campinas, Brazil). The authors thank Kristine Schmidt for proof-reading (language) of the manuscript.

Conflicts of Interest: The authors declare no conflict of interest.

\section{Abbreviations}

TDAP Tris(dimethylamino)phosphine

ATP Adenosine triphosphate

BINAP 2,2'-bis(diphenylphosphino)-1,1'-binaphthyl

$\mathrm{Bu}_{4} \mathrm{NPF}_{6} \quad$ Tetrabutylammonium hexafluorophosphate

$\left(\mathrm{CH}_{3}\right)_{3} \mathrm{SI} \quad$ Trimethylsulfonium iodide

$\mathrm{Li}\left(\mathrm{NTf}_{2}\right) \quad$ Lithium bis(trifluoromethanesulfonimide)

$\mathrm{Ph}_{3} \mathrm{PMeI} \quad$ Methyltriphenylphosphonium iodide

XPhos 2-Dicyclohexylphosphino-2' $\quad 4^{\prime}, 6^{\prime}$-triisopropylbiphenyl

\section{References}

1. Bull, J.A.; Croft, R.A.; Davis, O.A.; Doran, R.; Morgan, K.F. Oxetanes: Recent Advances in Synthesis, Reactivity, and Medicinal Chemistry. Chem. Rev. 2016, 116, 12150-12233. [CrossRef]

2. Berthelot, M.; Besseau, F.; Laurence, C. The Hydrogen-Bond Basicity $\mathrm{pK}_{\mathrm{HB}}$ Scale of Peroxides and Ethers. Eur. J. Org. Chem. 1998, 5, 925-931. [CrossRef]

3. Besseau, F.; Luçon, M.; Laurence, C.; Berthelot, M. Hydrogen-Bond Basicity $\mathrm{pK}_{\mathrm{HB}}$ Scale of Aldehydes and Ketones. J. Chem. Soc. Perkin Trans. 1998, 2, 101-108. [CrossRef]

4. Wuitschik, G.; Carreira, E.M.; Wagner, B.; Fischer, H.; Parrilla, I.; Schuler, F.; Rogers-Evans, M.; Müller, K. Oxetanes in Drug Discovery: Structural and Synthetic Insights. J. Med. Chem. 2010, 53, 3227-3246. [CrossRef]

5. Wuitschik, G.; Rogers-Evans, M.; Buckl, A.; Bernasconi, M.; Märki, M.; Godel, T.; Fischer, H.; Wagner, B.; Parrilla, I.; Schuler, F.; et al. Spirocyclic Oxetanes: Synthesis and Properties. Angew. Chem. 2008, 120, 4588-4591. [CrossRef] 
6. Burkhard, J.A.; Wuitschik, G.; Plancher, J.-M.; Rogers-Evans, M.; Carreira, E.M. Synthesis and Stability of Oxetane Analogs of Thalidomide and Lenalidomide. Org. Lett. 2013, 15, 4312-4315. [CrossRef]

7. Rogers-Evans, M.; Knust, H.; Plancher, J.-M.; Carreira, E.M.; Wuitschik, G.; Burkhard, J.; Dong, B.; Carine, G. Adventures in Drug-like Chemistry Space: From Oxetanes to Spiroazetidines and Beyond! Chim. Int. J. Chem. 2014, 68, 492-499. [CrossRef]

8. Davis, O.A.; Bull, J.A. Recent Advances in the Synthesis of 2-Substituted Oxetanes. Synlett 2015, 26, 1283-1288. [CrossRef]

9. Davis, O.A.; Croft, R.A.; Bull, J.A. Synthesis of diversely functionalised 2,2-disubstituted oxetanes: Fragment motifs in new chemical space. Chem. Commun. 2015, 51, 15446. [CrossRef] [PubMed]

10. Morgan, K.F.; Hollingsworth, I.A.; Bull, J.A. 2-(Aryl-Sulfonyl)oxetanes as Designer 3-Dimensional Fragments for Fragment Screening: Synthesis and Strategies for Functionalisation. Chem. Commun. 2014, 50, 5203-5205. [CrossRef] [PubMed]

11. Blomgren, P.; Chandrasekhar, J.; Di Paolo, J.A.; Fung, W.; Geng, G.; Ip, C.; Jones, R.; Kropf, J.E.; Lansdon, E.B.; Lee, S.; et al. Discovery of Lanraplenib (GS-9876), a Once-Daily Spleen Tyrosine Kinase Inhibitor for Autoimmune Diseases. ACS Med. Chem. Lett. 2020, 11, 506-513. [CrossRef] [PubMed]

12. Silverman, R.B.; Holladay, M.W. Lead Discovery and Lead Modification. In The Organic Chemistry of Drug Design and Drug Action; Academic Press: Boston, MA, USA, 2014; pp. 19-122.

13. Akritopoulou-Zanze, I.; Hajduk, P.J. Kinase-Targeted Libraries: The Design and Synthesis of Novel, Potent, and Selective Kinase Inhibitors. Drug Discov. Today 2009, 14, 291-297. [CrossRef] [PubMed]

14. Searles, S.; Pollart, K.A.; Block, F. Oxetanes. VII. Synthesis from 1,3-Diols. Reactions of Oxetanes and of 1,3-Butanediol with Hydrogen Chloride, Hydrogen Bromide and Acetyl Chloride 1,2. J. Am. Chem. Soc. 1957, 79, 952-956. [CrossRef]

15. Picard, P.; Leclercq, D.; Bats, J.-P.; Moulines, J. An Efficient One-Pot Synthesis of Oxetanes from 1,3-Diols. Synthesis 1981, 550-551. [CrossRef]

16. Searles, S.; Nickerson, R.G.; Witsiepe, W.K. Oxetanes. IX. Structural and Solvent Effects in the Reaction of $\gamma$-Bromoalcohols with Base 1,2. J. Org. Chem. 1959, 24, 1839-1844. [CrossRef]

17. Grob, C.A.; Schiess, P.W. Heterolytic Fragmentation. A Class of Organic Reactions. Angew. Chem. Int. Ed. Engl. 1967, 6, 1-15. [CrossRef]

18. Grob, C.A. Mechanisms and Stereochemistry of Heterolytic Fragmentation. Angew. Chem. Int. Ed. Engl. 1969, 8, 535-546. [CrossRef]

19. Winter, B. Spirocyclic Ethers Related to Ambrox ${ }^{\circledR}$ : Synthesis and Structure-Odor Relationships. Helv. Chim. Acta 2004, 87, 1616-1627. [CrossRef]

20. Snyder, S.E.; Aviles-Garay, F.A.; Chakraborti, R.; Nichols, D.E.; Watts, V.J.; Mailman, R.B. Synthesis and Evaluation of 6,7-Dihydroxy-2,3,4,8,9,13b-Hexahydro-1H- benzo[6,7]cyclohepta[1,2,3-ef][3]benzazepine,6, 7-Dihydroxy-1,2,3,4,8,12b-hexahydroanthr[10,4a,4-Cd]azepine, and 10-(Aminomethyl)-9,10-Dihydro-1,2Dihydroxyanthracene as Conformationally Restricted Analogs of Beta-Phenyldopamine. J. Med. Chem. 1995, 38, 2395-2409. [CrossRef]

21. Sato, T.; Onuma, T.; Nakamura, I.; Terada, M. Platinum-Catalyzed Cycloisomerization of 1,4-Enynes via 1,2-Alkenyl Rearrangement. Org. Lett. 2011, 13, 4992-4995. [CrossRef]

22. Castro, B.R. Replacement of Alcoholic Hydroxyl Groups by Halogens and Other Nucleophiles via Oxyphosphonium Intermediates. Org. React. 2005, 29, 1-162. [CrossRef]

23. Castro, B.; Selve, C. Sels D’alkyloxyphosphonium. VI-Nouvelle Preparation Des Dialkyl-3,3 Oxetannes. Tetrahedron Lett. 1973, 14, 4459-4460. [CrossRef]

24. Liwosz, T.W.; Chemler, S.R. Copper-Catalyzed Oxidative Amination and Allylic Amination of Alkenes. Chem. Eur. J. 2013, 19, 12771-12777. [CrossRef]

25. Brown, H.C.; Rao, B.C.S. A New Technique for the Conversion of Olefins into Organoboranes and Related Alcohols. J. Am. Chem. Soc. 1956, 78, 5694-5695. [CrossRef]

26. Zimmerman, H.E.; Nesterov, E.E. Quantitative Cavities and Reactivity in Stages of Crystal Lattices: Mechanistic and Exploratory Organic Photochemistry. J. Am. Chem. Soc. 2002, 124, 2818-2830. [CrossRef]

27. Thongsornkleeb, C.; Danheiser, R.L. A Practical Method for the Synthesis of 2-Alkynylpropenals. J. Org. Chem. 2005, 70, 2364-2367. [CrossRef] 
28. Croft, R.A.; Mousseau, J.J.; Choi, C.; Bull, J.A. Structurally Divergent Lithium Catalyzed Friedel-Crafts Reactions on Oxetan-3-Ols: Synthesis of 3,3-Diaryloxetanes and 2,3-Dihydrobenzofurans. Chem. Eur. J. 2016, 22, 16271-16276. [CrossRef]

29. Chen, L.; Yin, X.-P.; Wang, C.-H.; Zhou, J. Catalytic Functionalization of Tertiary Alcohols to Fully Substituted Carbon Centres. Org. Biomol. Chem. 2014, 12, 6033-6048. [CrossRef]

30. Thompson, A.L.S.; Kabalka, G.W.; Akula, M.R.; Huffman, J.W. The Conversion of Phenols to the Corresponding Aryl Halides Under Mild Conditions. Synthesis 2005, 2005, 547-550. [CrossRef]

31. Martz, K.E.; Dorn, A.; Baur, B.; Schattel, V.; Goettert, M.I.; Mayer-Wrangowski, S.C.; Rauh, D.; Laufer, S.A. Targeting the Hinge Glycine Flip and the Activation Loop: Novel Approach to Potent p38 $\alpha$ Inhibitors. J. Med. Chem. 2012, 55, 7862-7874. [CrossRef]

32. Wolfe, J.P.; Buchwald, S.L. Palladium-Catalyzed Amination of Aryl Triflates. J. Org. Chem. 1997, 62, $1264-1267$. [CrossRef]

33. Åhman, J.; Buchwald, S.L. An Improved Method for the Palladium-Catalyzed Amination of Aryl Triflates. Tetrahedron Lett. 1997, 38, 6363-6366. [CrossRef]

34. Koeberle, S.C.; Fischer, S.; Schollmeyer, D.; Schattel, V.; Grütter, C.; Rauh, D.; Laufer, S.A. Design, Synthesis, and Biological Evaluation of Novel Disubstituted Dibenzosuberones as Highly Potent and Selective Inhibitors of p38 Mitogen Activated Protein Kinase. J. Med. Chem. 2012, 55, 5868-5877. [CrossRef] [PubMed]

35. Niesen, F.H.; Berglund, H.; Vedadi, M. The Use of Differential Scanning Fluorimetry to Detect Ligand Interactions That Promote Protein Stability. Nat. Protoc. 2007, 2, 2212-2221. [CrossRef]

36. Huynh, K.; Partch, C.L. Analysis of Protein Stability and Ligand Interactions by Thermal Shift Assay. Curr. Protoc. Protein Sci. 2015, 79, 28.9.1-28.9.14. [CrossRef]

37. Shen, H.; Hu, Y.; Zhang, Y.; Zhou, X.; Xu, Z. Calcium-calmodulin Dependent Protein Kinase I from Macrobrachium Nipponense: cDNA Cloning and Involvement in Molting. Gene 2014, 538, $235-243$. [CrossRef]

38. Louis, J.V.; Lu, Y.; Pieschl, R.; Tian, Y.; Hong, Y.; Dandapani, K.; Naidu, S.; Vikramadithyan, R.K.; Dzierba, C.; Sarvasiddhi, S.K.; et al. [3H]BMT-046091 a Potent and Selective Radioligand to Determine AAK1 Distribution and Target Engagement. Neuropharmacology 2017, 118, 167-174. [CrossRef]

39. Kostich, W.; Hamman, B.D.; Li, Y.-W.; Naidu, S.; Dandapani, K.; Feng, J.; Easton, A.; Bourin, C.; Baker, K.; Allen, J.; et al. Inhibition of AAK1 Kinase as a Novel Therapeutic Approach to Treat Neuropathic Pain. J. Pharmacol. Exp. Ther. 2016, 358, 371-386. [CrossRef]

40. Neveu, G.; Ziv-Av, A.; Barouch-Bentov, R.; Berkerman, E.; Mulholland, J.; Einav, S. AP2-Associated Protein Kinase 1 and Cyclin G-Associated Kinase Regulate Hepatitis C Virus Entry and Are Potential Drug Targets. J. Virol. 2015, 89, 4387-4404. [CrossRef]

41. Bekerman, E.; Neveu, G.; Shulla, A.; Brannan, J.; Pu, S.-Y.; Wang, S.; Xiao, F.; Barouch-Bentov, R.; Bakken, R.R.; Mateo, R.; et al. Anticancer Kinase Inhibitors Impair Intracellular Viral Trafficking and Exert Broad-Spectrum Antiviral Effects. J. Clin. Investig. 2017, 127, 1338-1352. [CrossRef]

Publisher's Note: MDPI stays neutral with regard to jurisdictional claims in published maps and institutional affiliations.

(C) 2020 by the authors. Licensee MDPI, Basel, Switzerland. This article is an open access article distributed under the terms and conditions of the Creative Commons Attribution (CC BY) license (http://creativecommons.org/licenses/by/4.0/). 